\title{
Cellular and Immunological Response of THP-1 Cells in Response to Lipopolysaccharides and Lipoteichoic Acid Exposure
}

\author{
Nadukkandy Prajitha, Parayanthala Valappil Mohanan*
}

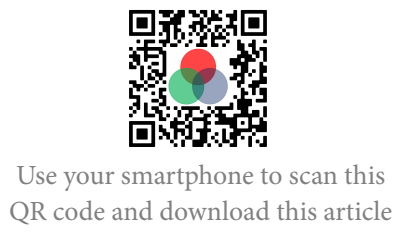

Toxicology Division, Biomedical Technology Wing, Sree Chitra Tirunal Institute for Medical Sciences and Technology (Govt. of India), Poojapura, Trivandrum 695012, Kerala, India

\section{Correspondence}

Parayanthala Valappil Mohanan, Toxicology Division, Biomedical Technology Wing, Sree Chitra Tirunal Institute for Medical Sciences and Technology (Govt. of India), Poojapura, Trivandrum 695012, Kerala, India

Email: mohanpv@sctimst.ac.in

\section{History}

- Received: Sep 09, 2021

- Accepted: Sep 24, 2021

- Published: Sep 30, 2021

DOI : 10.15419/bmrat.v8i9.693

\section{Check for updates}

\section{Copyright}

(c) Biomedpress. This is an openaccess article distributed under the terms of the Creative Commons Attribution 4.0 International license.

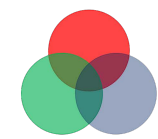

BioMedPress The Open Access Publisher

\begin{abstract}
Introduction: Bacterial toxins are considered to be obscuring factors in multiple human diseases Accidental contamination by bacterial lipopolysaccharides (LPS) and lipoteichoic acid (LTA) in biomedical and biotechnological products may lead to inflammation and associated pyrogenic reactions in humans. LPS are the most studied and clinically important pyrogen from gram-negative bacteria, while LTA is derived from the cell wall of gram-positive bacteria. Previous studies have identified that LPS and LTA induce a pyrogenic response in living systems. However, the detailed mechanisms of cellular toxicity have not yet been determined. The present study aimed to investigate LPS-induced and LTA-induced immune response activation and the ensuing effects on cellular integrity and organelle function in monocytes and monocyte-derived macrophages. Methods: With monocytes and macrophages being the first lines of defense against pathogenic invasion, THP-1 cells were selected as an in vitro model for the present study. THP-1 is a cancerous monocyte cell line and can differentiate into macrophages via stimulation with phorbolmyristic acid. Intracellular responses of monocytes and monocyte-derived macrophages following exposure to LPS and LTA were analyzed through several assays, including MTT, Neutral red, DCFH-DA, NO release, DilCI (5), Annexin V-PI FACS, Rhodamine phalloidine, Acridine Orange, and JC1. The expression of the inflammation-related genes NF $\kappa \mathrm{B}, \mathrm{COX} 2, \mathrm{IL}-1 \beta$, and TNF- $\alpha$, along with activation of inflammatory signaling, was also assessed in monocytes following toxic interaction. Results \& Conclusion: The results revealed that LPS and LTA can induce inflammatory signals at nanogram concentrations but are non-cytotoxic at low concentrations. LPS exposure had no significant toxic impacts on membrane integrity and organelle function. LPS induced neither apoptotic nor necrotic cell death of THP-1 cells at the selected concentration. However, LTA caused cell membrane damage and organelle dysfunction in a time and dose-dependent manner. LTA exposure led to oxidative stress and apoptotic cell death mediated by reactive oxygen species (ROS) and reactive nitrogen species (RNS). Both bacterial toxins augmented the expression of inflammatory genes and associated inflammatory signal transmission in THP-1 cells. The overall cellular effect was dependent on dose and time of exposure.
\end{abstract}

Key words: LPS, LTA, Inflammation, Pyrogen, Cytotoxicity

\section{INTRODUCTION}

Biomaterials, medical devices, injectables, and pharmaceuticals intended for use on living subjects should be non-toxic and biocompatible. Contamination of medical products or devices with a chemical or biological agent is a major challenge faced by clinicians and pharmaceutical manufacturers. All medical products should be free from toxic contamination and biological risks, such as inflammatory responses, fever, and febrile reactions, that are associated with their use on living subjects. Screening of medical products for pyrogens is a mandatory regulatory requirement. Pyrogens induce fever or febrile reactions in humans and animals. The term pyrogen is derived from the Greek word "pyr," meaning fever. Fever and febrile reactions are represented by an elevated body temperature above the normal physiological range $\left(36.5^{\circ} \mathrm{C}-37.5^{\circ} \mathrm{C}\right)$. Under normal circumstances, fever and febrile reactions are beneficial for hosts to fight against infection or injury. However, chronic immune activation associated with fever will result in cellular toxicity, hyper-activation of cytokines, and systemic inflammation. Pyrogenic fever is the most common adverse effect reported following the administration of contaminated pharmaceuticals ${ }^{1}$, implanted devices, and biotechnological products $^{2}$. Pyrexia is the term commonly used to denote pyrogen-mediated fever. Complications associated with pyrexia depend on the type and complexity of the associated pyrogens, the immunity of an affected individual, and genotypic and phenotypic differences in heat tolerance of an individual. Hyperthermic reactions may lead to heatstroke, multiple organ failure, 
or, in extreme cases, death ${ }^{3}$.

Most biotechnological products intended for clinical applications are based on recombinant proteins, antibodies, or plasmids synthesized or isolated from bacterial species, particularly Escherichia coli (E. coli). Therefore, these preparations involve some risk of bacterial contamination. Introduction of bacterial cell components (pyrogenic contamination) may result in inflammation and toxic shock. External antigens such as bacteria, viruses, fungi, chemicals, and leachates on medical devices act as exogenous pyrogens. Bacterial lipopolysaccharides (LPS) are the most potent and harmful exogenous pyrogens. LPS are endotoxins that originate from the cell walls of gram-negative bacteria.

Lipoteichoic acid (LTA) is a non-endotoxin pyrogen originating from gram-positive bacteria that plays a crucial role in initiating fever reactions. In every organism, the internal homeostatic mechanism is maintained by coordinating various physiological and biochemical processes. In humans, the pre-optic area of the anterior hypothalamus (POA) acts as the principal thermoregulatory center of the brain. Thermoreceptors in the hypothalamus receive signals related to temperature fluctuation in the internal environment, whereas skin thermoreceptors receive signals from the external environment. Synchronized action of the central nervous system (CNS) and endocrine hormones sustains the body's temperature in a narrow physiological range 4 .

Immuno-toxic response against most pyrogens begins with the release of inflammatory cytokines. Pyrogen-induced variation of body temperature is achieved through cytokine signaling and the release of eicosanoid mediators in the CNS. Eicosanoids are signaling molecules produced by the oxidation of polyunsaturated fatty acids, such as arachidonic acid. The eicosanoid prostaglandin (PG) E2 (PGE2) plays a central role in the elevation of body temperature during a pyrogenic attack. PG H/G synthase or cyclooxygenase (COX) act as the myeloperoxidase that catalyzes the rate-limiting step of PG synthesis from arachidonic acid. There are two isoforms of COX, COX1, and COX2. COX2 is regulated by growth factors, interleukin-1beta (IL1- $\beta$ ), interleukin-6 (IL-6), and tumor necrosis factor-alpha (TNF- $\alpha$ ), and is consequently overexpressed during inflammation. COX2 mediates the production of PGE2, PGD2, PGI2, and thromboxane A2, with PGE2 exerting significant effects on the CNS ${ }^{5}$. Following administration of LPS, elevated expression of COX2 mRNA has been reported in various areas of rat brains, including in the leptomeninges, neocortex, cingulate cortex, piriform cortex, hippocampus, lateral amygdala, thalamus, hypothalamus, striatum, preoptic area, blood vessels, perivascular monocytes, and endothelial cells ${ }^{6,7}$.

The human immune system involves a wide network of organs and cells that defend against a large range of foreign invaders, injuries, and infections. Immune cells that play significant roles in pathogen defense include monocytes, macrophages, and dendritic cells. In mammals, circulating monocytes protect against bacterial toxins. THP-1 cells are considered a suitable model for immuno-toxicity studies as they possess the structural and functional characteristics of human monocytes. Recently, Długosz et al. (2019) reported that cytokine signaling via THP-1 monocytes follows infection with the parasite Toxocara canis and its glycans. To prove the possible route of the immune response against parasitic infection, they used THP-1 cells as the cell model ${ }^{8}$. Phorbol 12-myristate 13-acetate (PMA) mediated differentiation of THP-1 monocytes is a well-established technique to analyze the in vitro response of macrophages to various toxins, including pandemic viral agents ${ }^{9}$. The present study focused on the in-depth mechanism of the cellular and immunological responses of THP-1 cells when exposed to LPS and LTA.

\section{METHODS}

\section{Cell culture and passage}

THP-1 cells were purchased from National Centre for Cell Science, Pune, India. THP-1 is a cancerous monocytic non-adhering cell maintained in RPMI1640 medium modified to contain $2 \mathrm{mM}$ L-glutamine, $10 \mathrm{mM}$ HEPES, $1 \mathrm{mM}$ sodium pyruvate, $4500 \mathrm{mg} / \mathrm{L}$ glucose, $1500 \mathrm{mg} / \mathrm{L}$ sodium bicarbonate, and 10\% fetal bovine serum. Cells were sub-cultured into a new tissue culture flask when the concentration reached $8 \times 10^{5}$ cells $/ \mathrm{mL}$. A new vial of cells was revived and maintained for the study after every five passages. THP-1 cells possess large, round, single-shaped morphology with a diameter of $18 \mu \mathrm{m}$ to $21 \mu \mathrm{m}$.

\section{Monocyte-macrophage differentiation}

THP-1 monocytes were treated with PMA to activate their differentiation into macrophages, known as monocyte-derived macrophages (MDMs). Phasecontrast images of the cells were taken under a compound microscope (Leica, Japan) to analyze the difference in morphological characteristics of monocytes and MDMs. 


\section{Cytotoxicity Analysis Giemsa staining}

The microscopic nuclear stain Giemsa was used to analyze the morphological characteristics of MDM cells following treatment with LPS and LTA. The Giemsa stain is commonly used to stain blood cells. The Giemsa stain stains the nucleus deep purple, while the cytoplasm appears pink. For staining purposes, $1 \mathrm{x}$ $10^{5}$ cells $/ \mathrm{mL}$ were seeded over sterile coverslips placed in a 6-well plate. The cells, along with PMA, were incubated at $37^{\circ} \mathrm{C}$ with $5 \% \mathrm{CO}_{2}$ for 24 hours. After incubation, the cells were exposed to set concentrations of LPS $(0.25,1$, and $5 \mathrm{EU} / \mathrm{mL})$ and LTA $(0.1,10$, and $1000 \mu \mathrm{g} / \mathrm{mL}$ ) for 24 hours. The next day, cells were washed three times with sterile phosphate buffered saline (PBS) and fixed using 4\% formaldehyde for 15 minutes. The cells were washed again with PBS to remove excess fixative. After fixation, the cells were stained with $10 \%$ Giemsa for 5 minutes, then washed three times with PBS. Morphologic analysis was done using a compound microscope under 40x magnification (Leica, Japan).

\section{Rhodamine phalloidin staining}

Morphological integrity of the cells was maintained by actin, a highly organized structural protein that provides mechanical strength to the cell cytoskeleton. Rhodamine phalloidine is a conjugate of the non-fluorescent F-actin-binding protein, phalloidin, and the red fluorescent compound, tetramethylrhodamine. The stain shows an excitation/emission wavelength of $540 \mathrm{~nm}-565 \mathrm{~nm}$. Thus, rhodamine phalloidine stains the actin filament with red fluorescence. For the assay, cells were taken at a density of $1 \mathrm{x}$ $10^{5}$ cells $/ \mathrm{mL}$, seeded over a coverslip placed in a 6-well plate, and incubated overnight for attachment. After 24 hours of incubation, the cells were exposed to set concentrations of LPS $(0.25,0.5,1,2$, and $5 \mathrm{EU} / \mathrm{mL})$ and $\operatorname{LTA}(0.1,1,10,100$, and $1000 \mu \mathrm{g} / \mathrm{mL})$. Cells were further incubated at $37^{\circ} \mathrm{C}$ with $5 \% \mathrm{CO}_{2}$ for 24 hours. The following day, the cells were washed with PBS and fixed using 4\% formaldehyde for 10 minutes. Excess aldehyde was quenched using 0.1 M glycine in PBS for 5 minutes. To permeabilize the cell membranes, $0.1 \%$ Triton-X 100 (in PBS) was added. Permeabilized cells were incubated with rhodamine-phalloidin (1:250 dilutions in PBS) for 15 minutes at room temperature. The nucleus was counterstained with the blue fluorescent dye DAPI. Cells were thoroughly washed with sterile PBS and were imaged under blue $(461 \mathrm{~nm})$ and red $(620 \mathrm{~nm})$ fluorescence microscope filters (Axio Scope.A1, Carl Zeiss, Germany).

\section{MTT assay}

The functional integrity of mitochondria is necessary for maintaining the viability of living cells, and 3(4, 5-dimethylthiazol-2-yl)-2,5-diphenyltetrazolium bromide (MTT) is widely used to assess cell's mitochondrial reduction potential, and therefore their viability. This method utilizes the principle of MTT oxidizing and reducing to an insoluble purple-colored product, known as formazan. The intensity of the purple color formed is directly proportional to the number of active mitochondria in cells. For the assay, cells were seeded into a 96 -well plate at a density of $1 \mathrm{x}$ $10^{4}$ cells $/ \mathrm{mL}$ and incubated at $37^{\circ} \mathrm{C}$ with $5 \% \mathrm{CO}_{2}$ for $24 \mathrm{~h}$. After incubation, the cells were treated with set concentrations of LPS $(0.25,0.5,1,2$, and $5 \mathrm{EU} / \mathrm{mL})$ and $\operatorname{LTA}(0.1,1,10,100$, and $1000 \mu \mathrm{g} / \mathrm{mL})$. Cells were exposed to the toxicants for 24 hours, 48 hours, and 72 hours at $37^{\circ} \mathrm{C}$ with $5 \% \mathrm{CO}_{2}$. After incubation, the supernatant was removed, and $0.05 \mathrm{mg} / \mathrm{mL}$ of MTT dye was added to each well. The plate was incubated for 3 hours in the dark. Following incubation, the cells were washed with PBS, and $100 \mu \mathrm{L}$ DMSO was added to each well. The plate was again incubated in the dark for 30 minutes at room temperature. The optical density of the purple color was measured at $540 \mathrm{~nm}$ using ELx808 multiwell plate reader (BioTek Instruments, USA). A graph was plotted as the percentage of mitochondrial activity in treated cells compared to the untreated control.

\section{Neutral red uptake (NRU) assay}

Lysosomes are phagocytic vesicles present inside the cells. Phagocytosis of neutral red dye by healthy lysosomes indicates their functional integrity. Cellular viability following LPS and LTA treatment was analyzed as a function of lysosomal activity. Cells at a density of $1 \times 10^{4}$ cells $/ \mathrm{mL}$ were cultured in a 96-well plate and incubated at $37^{\circ} \mathrm{C}$ with $5 \% \mathrm{CO}_{2}$ for 24 hours. After incubation, the cells were exposed to concentrations of LPS $(0.25,0.5,1,2$, and $5 \mathrm{EU} / \mathrm{mL})$ and LTA $(0.1,1,10,100$, and $1000 \mu \mathrm{g} / \mathrm{mL})$ for 24 hours, 48 hours, or 72 hours. The following day, the supernatant was removed from each well, and $10 \mu \mathrm{L}$ of $1 \%$ neutral red dye was added. The cells were then incubated in the dark for 3 hours. Following incubation, the cells were washed with PBS, and the dye was solubilized using $100 \mu \mathrm{L}$ acid alcohol (1\% [v/v] acetic acid and $50 \%$ ethanol). Cells were agitated in a shaker incubator for 30 minutes at $60 \mathrm{rpm}$. Absorbance was measured at $540 \mathrm{~nm}$ using an ELx808 multiwell plate reader (BioTek Instruments, USA). 


\section{2'7'-Dichlorofluorescein diacetate assay}

The fluorescent probe $2^{\prime} 7^{\prime}$-dichlorofluorescein diacetate (DCFH-DA) is used as an indicator of reactive oxygen species (ROS) generation within cells. The non-fluorescing DCFH-DA dye is freely permeable through the cell membrane and undergoes deacetylation by intracellular esterase enzymes. The deacetylated $2^{\prime}, 7^{\prime}$-dichlorofluorescein (DCFH) oxidizes to form a highly fluorescent green compound dichlorofluorescein (DCF) by the action of ROS generated inside the cells. Here, the presence of ROS inside the cells following LPS and LTA exposure for a period of 1 hour, 3 hours, 24 hours, 48 hours, and 72 hours was analyzed using DCFH-DA. Cells at a density of $1 \mathrm{x}$ $10^{4}$ cells $/ \mathrm{mL}$ seeded in a 96-well plate were allowed to attach overnight. Cells were exposed to concentrations of LPS $(0.25,0.5,1,2$, and $5 \mathrm{EU} / \mathrm{mL})$ and LTA $(0.1,1,10,100$, and $1000 \mu \mathrm{g} / \mathrm{mL})$ and incubated at $37^{\circ} \mathrm{C}$ with $5 \% \mathrm{CO}_{2}$ and $5 \mu \mathrm{M}$ DCFH-DA for the required period of time. After incubation, the supernatant medium was replaced with PBS. Fluorescence intensity was measured using the Infinite F Nano+ and the Tecan fluorescence plate reader at an excitation and emission wavelength of $485 \mathrm{~nm}$ and $530 \mathrm{~nm}$, respectively.

\section{Griess reagent assay}

The production of reactive nitrogen species (RNS) was analyzed using a modified Griess assay. Naphthyl ethylenediamine dihydrochloride and sulphanilamide, which are present in the Griess reagent, react with nitrite released from cells to form a purple azo product. The absorbance of the product formed is directly proportional to the number of RNS generated inside the cells. A 96-well plate was seeded with cells at a density of $1 \times 10^{4}$ cells $/ \mathrm{mL}$ and incubated at $37^{\circ} \mathrm{C}$ with $5 \% \mathrm{CO}_{2}$ overnight. The following day, after removing the supernatant medium, the cells were treated with LPS $(0.25,0.5,1,2$, and $5 \mathrm{EU} / \mathrm{mL})$ and LTA $(0.1,1,10,100$ and $1000 \mu \mathrm{g} / \mathrm{mL})$ for 24 hours, 48 hours, or 72 hours. After incubation, $50 \mu \mathrm{L}$ of supernatant was taken from each well and mixed with an equal volume of Griess reagent. The mixture was allowed to stand at room temperature for 10 minutes. Absorbance was measured at $540 \mathrm{~nm}$ using a multiwell plate reader (BioTek, USA). The concentration of nitrite released in the supernatant of treated cells was calculated using a standard graph plotted using sodium nitrite as a substrate because nitrite $\left(\mathrm{NO}_{2}^{-}\right)$, is one of two primary, stable and nonvolatile breakdown products of NO.

\section{Acridine orange (AO) fluorescent staining}

Lysosomes are known as the suicide bags of living cells. Destabilization of the lysosomal membrane causes the release of vesicular hydrolytic enzymes into the cytosol. AO is a DNA intercalating agent and a cationic fluorochrome that diffuses through the cell membrane. The fluorescence emitted by AO depends on the $\mathrm{pH}$ of the medium. At an acidic $\mathrm{pH}$, the dye becomes protonated and emits an orange-red fluorescence, whereas, at an alkaline $\mathrm{pH}$, it remains green in color. Therefore, healthy lysosomes emit red fluorescence after staining with AO. For the assay, $5 \mathrm{x}$ $10^{4}$ cells $/ \mathrm{mL}$ were seeded in a 6 -well plate containing sterile coverslips. Cells were incubated for 24 hours to allow attachment to the coverslip. After incubation, the cells were treated with LPS $(0.25,0.5,1,2$, and 5 $\mathrm{EU} / \mathrm{mL})$ and LTA $(0.1,1,10,100 \mathrm{~m}$ and $1000 \mu \mathrm{g} / \mathrm{mL})$ for 24 hours. The following day, live cells were stained with $1 \mathrm{~mL}$ of $\mathrm{AO}$ solution $(2 \mu \mathrm{g} / \mathrm{mL}$ in PBS) for 20 minutes at $37^{\circ} \mathrm{C}$. For qualitative analysis of the lysosomes, an image was taken under green and red fluorescent microscope filters (Axio scope A1, Carl Zeiss).

\section{DilCI (5) fluorescence-activated cell sorting (FACS) analysis}

Analysis of mitochondrial membrane potential (MMP) following exposure to LPS and LTA was carried out using the MitoProbe ${ }^{\mathrm{TM}}$ DiIC1 (5) Assay Kit. The kit provides red fluorescent cyanine dye DiIC1 (5) (1,1' ${ }^{\prime}, 3,3,3^{\prime}, 3^{\prime}$-hexamethylindodicarbocyanine iodide) and an MMP distracting compound, carbonyl cyanide 3-chlorophenylhydrazone (CCCP). DiICI (5) dye specifically stains active mitochondria. Therefore, a decrease in the intensity of DiICI (5) fluorescence indicates a decrease in the number of healthy mitochondria inside cells. Cells at a density of $1 \times 10^{6}$ cells $/ \mathrm{mL}$ were seeded in a 6-well plate and incubated at $37^{\circ} \mathrm{C}$ with $5 \% \mathrm{CO}_{2}$ for 24 hours. The cells were treated with selected concentrations of LPS $(1,2$, and $5 \mathrm{EU} / \mathrm{mL})$ and LTA $(10,100$, and 1000 $\mu \mathrm{g} / \mathrm{mL}$ ) for 24 hours. The following day, the cells were harvested and centrifuged at $1200 \mathrm{rpm}$ for 3 minutes. Cell pellets were washed three times with sterile PBS. After washing, the cells were stained with a $0.5 \mu \mathrm{M}$ concentration of DilCI (5) for 30 minutes at $37^{\circ} \mathrm{C}$. The positive control had $1 \mu \mathrm{L} \mathrm{CCCP}$ added. After incubation, cells were washed with PBS, and FACS analysis was done under an excitation/emission filter of $638 \mathrm{~nm}$ to $658 \mathrm{~nm}$ using a Beckman Coulter flow cytometer. 


\section{Fluorescence imaging by JC1 probe}

Mitochondrial membrane potential was also analyzed with a fluorescent carbocyanine probe, JC1 (5,5',6,6'-tetrachloro-1,1',3,3'-tetraethylbenzimidazolylcarbocyanine iodide). Mitochondria that possess a specified range of membrane potential emit red fluorescence after JC1 staining. JC1 is a lipophilic dye that enters the mitochondria and polymerizes to form J-aggregates, which, in turn, emit red fluorescence. JC1 emits green fluorescence in the cytoplasm, where it exists as a J-monomer. Cells were seeded at a density of $5 \times 10^{4}$ cells $/ \mathrm{mL}$ over sterile coverslips placed in a 6 -well plate. The confluent culture was then exposed to concentrations of LPS $(0.25,1$, and $5 \mathrm{EU} / \mathrm{mL})$ and LTA $(0.1,10$, and $1000 \mu \mathrm{g} / \mathrm{mL}$ ) for 24 hours. Following exposure, cells were stained with $1 \mu \mathrm{M}$ JC-1 dye at room temperature for 20 minutes. After staining, cells were washed three times with sterile PBS to remove excess dye. JC1-stained mitochondria were observed under a fluorescence microscope (Axio Scope.A1, Carl Zeiss, Germany) using green and red filters.

\section{Lactate dehydrogenase (LDH) release assay}

$\mathrm{LDH}$ is a cytosolic enzyme involved in the carbohydrate metabolism of almost all cells in the human body. Any destruction of the plasma membrane results in will the release of $\mathrm{LDH}$ from inside the cells into the extracellular medium. In this assay, the release of LDH into the extracellular medium following exposure to LPS and LTA was analyzed using a commercially available detection kit (CyQUANT ${ }^{\mathrm{TM}}$, Thermofisher Scientific). The analysis is based on the principle that $\mathrm{LDH}$ catalyzes the conversion of lactate to pyruvate via the reduction of $\mathrm{NAD}^{+}$to NADH. Diaphorase enzymes use this NADH to reduce tetrazolium salt (INT) into a red-colored formazan product measurable at $490 \mathrm{~nm}$. The concentration of formazan increases with an increase in the concentration of LDH released into the extracellular medium. For the assay, $1 \times 10^{4}$ cells $/ \mathrm{mL}$ were seeded into a 96-well plate and incubated overnight. Cells were then treated with LPS $(0.25,0.5,1,2$, and $5 \mathrm{EU} / \mathrm{mL})$ and LTA $(0.1$, $1,10,100$, and $1000 \mu \mathrm{g} / \mathrm{mL}$ ) for 24 hours, 48 hours, and 72 hours. After incubation, the cell culture supernatant was aspirated from each well, and $\mathrm{LDH}$ release was analyzed per the manufacturer's instructions.

\section{Live-dead assay by calcein-AM and propid- ium iodide}

The combination of calcein-AM and propidium iodide (PI) stains was used to assess the percentage of live and dead cell populations in cultures following exposure to LPS and LTA. Calcein-AM is permeable through the cell membrane, and it forms a polyanionic fluorescein derivative following hydrolysis by intracellular esterase enzymes. Calcein-AM-stained cells emit green fluorescence and are considered to be viable. PI is a nucleophilic dye that stains the nuclei of dead cells. PI can penetrate the cells with compromised plasma membranes and emit red fluorescence. In this assay, cells were seeded at a density of 1 $\mathrm{x} 10^{6}$ cells/mL over sterile coverslips placed in a 6-well plate. The plate was incubated at $37^{\circ} \mathrm{C}$ for 24 hours. The medium was removed the following day, and the cells were treated with concentrations of LPS $(0.25$, $0.5,1,2$, and $5 \mathrm{EU} / \mathrm{mL})$ and LTA $(0.1,1,10,100$, and $1000 \mu \mathrm{g} / \mathrm{mL}$ ) for 24 hours, 48 hours, and 72 hours. The supernatant medium was discarded, and the cells were washed with sterile PBS. Calcein-AM $(1 \mu \mathrm{g} / \mathrm{mL})$ was added to the wells, which were then incubated at $37^{\circ} \mathrm{C}$ for 40 minutes. The cells were then treated with PI $(2.5 \mu \mathrm{M})$ for 5 minutes. After staining, the cells were washed with PBS and observed under green and red fluorescence microscope filters (Axio Scope.A1, Carl Zeiss, Germany). Quantitative analysis was carried out by seeding cells in a 96-well plate at a density of $1 \times 10^{4}$ cells $/ \mathrm{mL}$. The same staining procedure as described above was carried out. Fluorescence was measured with a fluorescent microplate reader (Infinite F Nano+, Tecan) using an excitation/emission filter of $485 \mathrm{~nm}$ to $595 \mathrm{~nm}$.

\section{Apoptosis by annexin V/PI staining}

Annexin V/PI dual stains are widely used to detect the apoptotic and necrotic stages of cell death following exposure to test chemicals or compounds. Annexin V selectively interacts with phosphatidylserine (PS), which is located at the inner surface of the cell plasma membrane. During apoptosis, PS flips from the intracellular surface of the plasma membrane to the outer surface. This flipping enables annexin $\mathrm{V}$ to interact with PS. Therefore, annexin V only interacts with PS in apoptotic cells, emitting green fluorescence. PI stains the nuclei of dead or necrotic cells. Therefore, cells undergoing necrotic death emit red fluorescence. In the present study, this stain was carried out using a commercially available assay kit, with the manufacturer's instructions followed. Cells at a density 5 of 1 $\mathrm{x} 10^{6}$ cells $/ \mathrm{mL}$ were seeded in a 6 -well plate and incubated at $37^{\circ} \mathrm{C}$ with $5 \% \mathrm{CO}_{2}$ for 24 hours. After incubation, cells were exposed to LPS $(0.25,0.5,1,2$, and $5 \mathrm{EU} / \mathrm{mL})$ and $\operatorname{LTA}(0.1,1,10,100$, and $1000 \mu \mathrm{g} / \mathrm{mL})$ for 24 hours. The following day, the cells were harvested by trypsinization and centrifuged at $1200 \mathrm{rpm}$ 
for 5 minutes. The cell pellets were washed three times with cold PBS. After washing, the cells were stained with $5 \mu \mathrm{L}$ of annexin $\mathrm{V}$ in a $1 \mathrm{X}$ annexin binding buffer (ABB) for 10 minutes. Five minutes before the analysis, $1 \mu \mathrm{L}$ of PI ( $100 \mu \mathrm{g} / \mathrm{L})$ was added to each tube. The samples were kept on ice and immediately analyzed using an image flow cytometer (Amnis , FlowSight ${ }^{\circ}$ ) under fluorescence emissions of $530 \mathrm{~nm}$ and $575 \mathrm{~nm}$. Gating was done using specified controls: cells with annexin $\mathrm{V}$ only, cells without annexin or PI, and cells with PI only.

\section{Analysis of Immunological response Cytokine gene expression using quantitative real-time PCR}

Quantitative real-time polymerase chain reactions (qRT-PCR) were performed to analyze the expression of cytokine genes in MDM cells following 24 hours of exposure to LPS $(1,2$, and $5 \mathrm{EU} / \mathrm{mL})$ and LTA $(10,100$, and $1000 \mu \mathrm{g} / \mathrm{mL})$. RNA was isolated from treated and untreated cells using RNeasy Mini Kit as per the manufacturer's instructions. The concentration of RNA was estimated with a BioPhotometer (Eppendorf). RNA isolated from untreated controls and treated samples were kept frozen at $-20^{\circ} \mathrm{C}$ until use. First-strand complementary DNA (cDNA) was reverse transcribed from $200 \mathrm{ng}$ of total RNA using the reverse transcriptase core kit. Expressions of IL- $1 \beta$, TNF- $\alpha$, nuclear factor-kappa b (NF $\kappa \mathrm{B})$, and COX2 were analyzed using the Bio-Rad PCR system. PCRs were performed using the following amplification program, initial denaturation at $95^{\circ} \mathrm{C}$ for 1 minute, 35 cycles of 3 seconds of denaturation at $95^{\circ} \mathrm{C}, 30$ seconds annealing at $51^{\circ} \mathrm{C}-62^{\circ} \mathrm{C}$, and 15 second extensions at $72^{\circ} \mathrm{C}$. The program was terminated following 10 minutes at $72^{\circ} \mathrm{C}$. The reference gene $\beta$-actin (ACTB) was used to normalize the gene expression data. Amplification of genes and data analysis were carried out using system software. Primer sequences used for the PCR reactions are given in Table 1 .

\section{Immunocytochemistry analysis of NFKB p65}

Nuclear translocation of activated NFKB p65 in MDM cells following LPS exposure was analyzed using a fluorescence microscope. For fluorescence imaging, $1 \times 10^{5}$ cells $/ \mathrm{mL}$ were seeded over a coverslip placed in a single-well dish. Specific concentrations of LPS $(0.25,0.5,1,2$, and $5 \mathrm{EU} / \mathrm{mL})$ were added to corresponding wells and incubated for 24 hours. After LPS exposure, the cells were washed with PBS and fixed with $4 \%$ formaldehyde for 5 minutes. Cells were then washed again with PBS and permeabilized with Triton X100. Blocking of unwanted sites was done using $1 \%$ bovine serum albumin (BSA). Cells were then washed three times with PBS and incubated overnight with an anti-NFKB p65 primary antibody (1:500 dilution) at $4^{\circ} \mathrm{C}$. After incubation, the cells were washed another three times with PBS. Fluorescin isothiocyanate-tagged (FITC-tagged) secondary antibodies (1:500 dilution) were added, and the cells were then kept at room temperature for 2 hours. Cells were then washed with PBS, and the imaging was done under a fluorescence microscope (Axio Scope). Actin filaments and the nuclei of the cells were counterstained with rhodamine phalloidine and DAPI, respectively.

\section{Analysis of NFKB p65 activation by flow cy- tometry}

Activation of the NFKB pathway in MDM cells following exposure to selected concentrations of LPS and LTA was analyzed using an image flow cytometer. For the analysis, cells at a density of $1 \times 10^{6}$ cells $/ \mathrm{mL}$ were seeded in a 6-well plate and incubated at $37^{\circ} \mathrm{C}$ with $5 \% \mathrm{CO}_{2}$ for 24 hours. The following day, cells were treated with LPS $(0.25,1$, and $5 \mathrm{EU} / \mathrm{mL})$ and LTA $(0.1,10$, and $1000 \mu \mathrm{g} / \mathrm{mL})$, for 24 hours. Untreated cells served as the negative control. Treated and untreated cells were harvested from the wells and centrifuged at $1200 \mathrm{rpm}$ for 3 minutes. Cell pellets were washed with sterile PBS. After washing, the cells were fixed with $80 \%$ ethanol for 5 minutes. Permeabilzation was done using $0.1 \%$ Triton X100. After permeabilization, the cells were washed three times with PBS and incubated with an anti-NFKB p65 primary antibody (1:1000 dilution) overnight at $4^{\circ} \mathrm{C}$. Cells were washed again with sterile PBS and stained with the FITC-tagged secondary antibody. After incubation at room temperature for 2 hours, the cells were analyzed for NFKB activation using a green laser.

\section{COX2 activation by flow cytometry}

Pyrogenic response following exposure to LPS and LTA involves the release of PGs through the activation of the COX2 enzyme pathways. For the analysis, $1 \times 10^{6}$ cells $/ \mathrm{mL}$ were seeded in a 6-well plate and incubated at $37^{\circ} \mathrm{C}$ with $5 \% \mathrm{CO}_{2}$. The cells were treated with LPS $(0.25,1$, and $5 \mathrm{EU} / \mathrm{mL})$ and LTA $(0.1,10$, and $1000 \mu \mathrm{g} / \mathrm{mL}$ ) for 24 hours. Untreated cells served as the negative control. Treated and untreated cells were then centrifuged at $1200 \mathrm{rpm}$ for 3 minutes, after which the pellets were washed three times with sterile PBS. After fixation with $80 \%$ ethanol, cells were permeabilized with $0.1 \%$ Triton X100 for 1 minute. Fol- 
Table 1: Primer sequences used for the PCR reactions

\begin{tabular}{|c|c|c|}
\hline S.No & Genes & Primer Sequences \\
\hline 1 & IL-1beta & $\begin{array}{l}\text { FP: 5'-ATAAGCCCACTCTACAGCT-3' } \\
\text { RP: 5'-ATTGGCCCTGAAAGGAGAGA-3' }\end{array}$ \\
\hline 2 & TNF- $\alpha$ & $\begin{array}{l}\text { FP: 5'-CAGAGGGAAGAGTTCCCCAG-3' } \\
\text { RP: 5'-CCTTGGTCTGGTAGGAGACG-3' }\end{array}$ \\
\hline 3 & $\mathrm{NF} \kappa \mathrm{B}$ & $\begin{array}{l}\text { FP: 5'-CGCCGCTTAGGAGGGAGA-3' } \\
\text { RP: 5'-AGGTATGGGCCATCTGCTGT-3' }\end{array}$ \\
\hline 4 & $\mathrm{COX} 2$ & $\begin{array}{l}\text { FP: 5'-TCATCAACACTGCCTCAATTC-3' } \\
\text { RP: 5'-CTCTGGATCTGGAACACTGA-3' }\end{array}$ \\
\hline 5 & $\beta$-actin & $\begin{array}{l}\text { FP: 5'-AACTACCTTCAACTCCATCA-3' } \\
\text { RP: 5'-GAGCAATGATCTTGATCTTCA-3' }\end{array}$ \\
\hline
\end{tabular}

lowing an additional PBS wash, the cells were incubated with anti-COX2 primary antibody (1:1000 dilution) at $4^{\circ} \mathrm{C}$ for 24 hours. After incubation with the primary antibody, the cells were stained with the FITC-tagged secondary antibody. After incubation in the dark at room temperature for 2 hours, FACS analysis was carried out using a green laser.

\section{Statistical analysis}

The experiment was done in triplicates. The results of the MTT assay, neutral red uptake assay, ROS production assay, nitrile radical release assay, LDH assay, calcein-AM/PI assay, and annexin-PI assay are expressed as mean \pm standard deviation. Statistical significance was calculated using a Student's T-test. Pvalues less than 0.05 were considered significant and are denoted by ${ }^{*}$, $\mathrm{p}$-values less than 0.01 are denoted by ${ }^{* *}, \mathrm{p}$-values less than 0.001 are denoted by ${ }^{* * *}$.

\section{RESULTS}

Differentiation and cellular morphology by phase-contrast imaging

Differentiation of THP-1 monocytes to macrophages was observed under a phase-contrast microscope. The monocytes appeared to be round in morphology and existed in a suspension. Almost all of the cells (99\%) were deemed to be of ideal size and shape and treatment with the mitogen PMA induced terminal differentiation of monocytes to macrophages. MDM cells showed characteristic phenotypes of macrophages, with extended pseudopodia and granular cytoplasms, and were attached to the bottom of the culture dish. Cellular morphology became uneven following differentiation, with cytoplasmic extensions evident. Differentiated macrophages exhibited different sizes and shapes (Figure 1A). Changes in cellular morphology following 24 hours of exposure to LPS and LTA were analyzed using Giemsa staining. It was noted that there was no characteristic change in morphology or cell adhesion properties following 24 hours of exposure of LPS up to 5 EU/mL. Similarly, 0.1 to $100 \mu \mathrm{g} / \mathrm{mL}$ of LTA did not affect the morphological characteristics of the MDM cells. However, exposure of cells to $1000 \mu \mathrm{g} / \mathrm{mL}$ of LTA caused a loss of cytoplasmic extensions, meaning the cells appeared round in morphology (Figure 1B).

\section{Cytoskeletal integrity by rhodamine phal- loidin staining}

The cytoskeletal protein actin was stained with rhodamine phalloidine to assess its integrity. All untreated cells showed characteristic actin organization and adhered to the cell culture dish. No cytoskeletal rearrangement or actin destabilization was evident after 24 hours of exposure to 0.25 to $5 \mathrm{EU} / \mathrm{mL}$ of LPS (Figure 1C). Similarly, LTA exposure of 0.1 to 100 $\mu \mathrm{g} / \mathrm{mL}$ had no significant effect on actin organization. However, LTA exposure of $1000 \mu \mathrm{g} / \mathrm{mL}$ caused significant rearrangement of actin organization. This resulted in the loss of characteristic cellular morphology, and the cells became more fragile. Actin destabilization led to the detachment of cells from the culture dish, with the morphology of the cells changing to round in shape. A visible reduction in the number of cells was observed following $1000 \mu \mathrm{g} / \mathrm{mL}$ of LTA exposure for 24 hours (Figure 1D).

\section{Mitochondrial activity by MTT assay}

As shown in the graph Figure 2(I-A), it was observed that LPS did not affect mitochondrial oxidationreduction activity regardless of the dose MDM cells were exposed to. There was no significant reduction in formazan crystal formation in cells treated with 0.25 to $5 \mathrm{EU} / \mathrm{mL}$ of LPS for 24 hours, 48 hours, or 72 

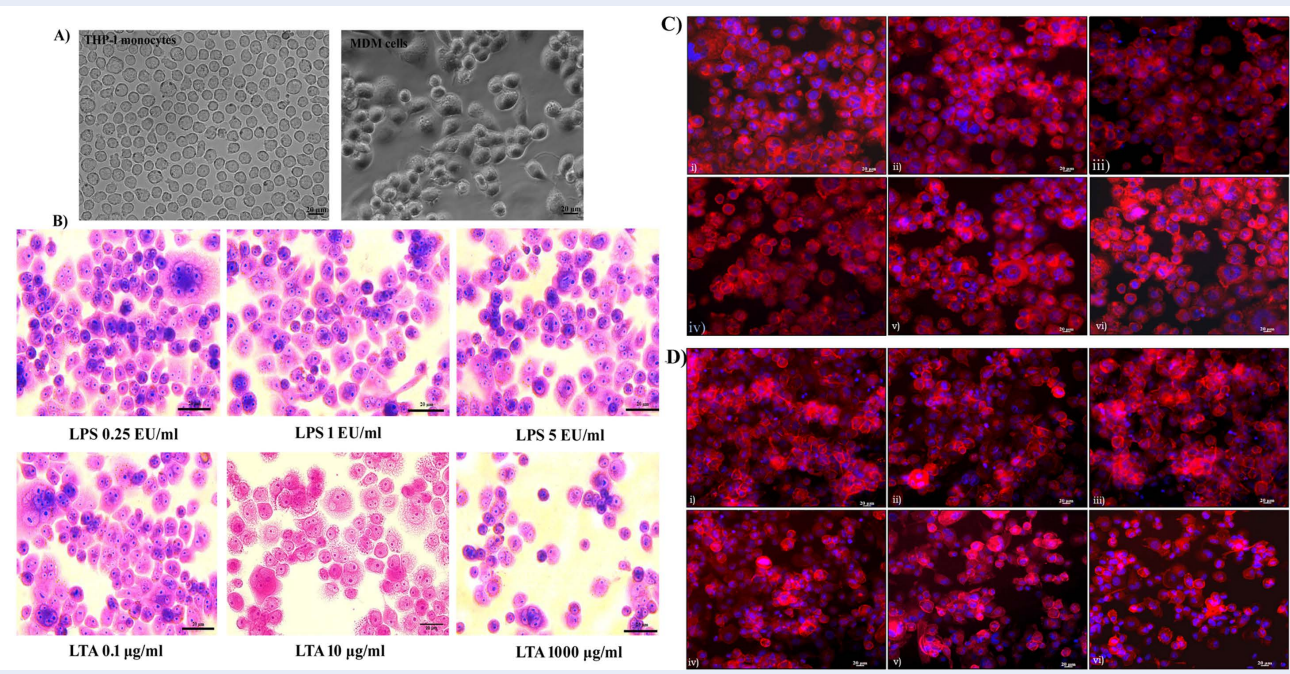

Figure 1: Analysis of monocyte differentiation and cellular morphology. A) Differentiation of THP-1 cells to MDM cells using PMA for 48h; B) Giemsa staining for analysis of cellular morphology following 24h exposure with LPS $(0.25 \mathrm{EU} / \mathrm{ml}, 1 \mathrm{EU} / \mathrm{ml}, 5 \mathrm{EU} / \mathrm{ml})$ and LTA $(0.1 \mu \mathrm{g} / \mathrm{ml}, 10 \mu \mathrm{g} / \mathrm{ml}, 1000 \mu \mathrm{g} / \mathrm{ml})$. Scale bar $20 \mu \mathrm{m}$, Magnification 40X. Rhodamine phalloidine staining of MDM cells; C) i) Control, ii) LPS $0.25 \mathrm{EU} / \mathrm{ml}$, iii) LPS $0.5 \mathrm{EU} / \mathrm{ml}$, iv) LPS1 EU/ml, v) LPS $2 \mathrm{EU} / \mathrm{ml}$, vi) LPS $5 \mathrm{EU} / \mathrm{ml}$; D) i) Control, ii) LTA $0.1 \mu \mathrm{g} / \mathrm{ml}$, iii) LTA $1 \mu \mathrm{g} / \mathrm{ml}$, iv) LTA $10 \mu \mathrm{g} / \mathrm{ml}, v)$ LTA $100 \mu \mathrm{g} / \mathrm{ml}$, vi) LTA $1000 \mu \mathrm{g} / \mathrm{ml}$ for $24 \mathrm{~h}$. Untreated cells were used as control. The scale bar represents $20 \mu \mathrm{m}$. Magnification $20 \mathrm{X}$. https://doi.org/10.6084/m9.figshare.16709176.v1

hours. The cellular mitochondrial function of LPStreated cells was highly comparable with that of untreated control cells. Mitochondria seemed to maintain normal levels of activity following exposure to LTA up to $10 \mu \mathrm{g} / \mathrm{mL}$ for $24 \mathrm{~h}$. Compared to untreated control cells, a statistically significant decrease in mitochondrial activity was observed in cells exposed to 100 and $1000 \mu \mathrm{g} / \mathrm{mL}$ of LTA. This reduction in mitochondrial activity was statistically significant $(\mathrm{p}<$ 0.001). When the exposure time to LTA increased to 48 hours, a gradual, significant reduction in mitochondrial activity was observed for concentrations of $100 \mu \mathrm{g} / \mathrm{mL}(\mathrm{p}<0.01)$ and $1000 \mu \mathrm{g} / \mathrm{mL}(\mathrm{p}<0.001)$. After 72 hours of exposure to LTA, a significant loss of mitochondrial oxidation-reduction potential was observed across all concentrations ( 0.1 to $1000 \mu \mathrm{g} / \mathrm{mL}$ ). Following 72 hours of exposure, an almost $40 \%-$ $60 \%$ reduction was observed for concentrations of 100 $\mu \mathrm{g} / \mathrm{mL}(43.04 \pm 0.002, \mathrm{p}<0.1)$ and $1000 \mu \mathrm{g} / \mathrm{ml}(35.7$ $\pm 0.003, \mathrm{p}<0.01$; Figure $2[\mathrm{I}-\mathrm{B}])$.

\section{Lysosomal activity by neutral red uptake assay}

Functional activity of lysosomes was quantitatively analyzed using a neutral red uptake assay for a period of 24 to 72 hours. It was noted that LPS did not induce a loss of lysosomal activity in MDM cells compared to negative control cells following 24 hours, 48 hours, and 72 hours of exposure. However, 48 hours and 72 hours of exposure to a $2 \mathrm{EU} / \mathrm{mL}$ concentration of LPS showed a statistically significant decrease in lysosomal activity $(\mathrm{p}<0.05)$, despite more than $80 \%$ of cells still being viable at this concentration (Figure 2 [I-C]). As in the MTT assay, 24 hours of exposure to LTA caused a significant reduction in lysosomal activity at concentrations of $100 \mu \mathrm{g} / \mathrm{mL}(\mathrm{p}<0.05)$ and 1000 $\mu \mathrm{g} / \mathrm{mL}(\mathrm{p}<0.01)$. LTA exposure induced a decline in lysosomal activity in a dose and time-dependent manner. After 48 hours and 72 hours of exposure to LTA, there was a drastic decline in the functional activity of lysosomes at LTA concentrations of $100 \mu \mathrm{g} / \mathrm{mL}$ (p < $0.01)$ and $1000 \mu \mathrm{g} / \mathrm{mL}(\mathrm{p}<0.01)$. Exposure to 1000 $\mu \mathrm{g} / \mathrm{mL}$ of LTA caused a loss of lysosomal activity in $47 \%$ of cells following 72 hours of exposure compared to untreated cells (Figure 2[I-D]).

\section{Free radical generation by DCFHDA assay}

Quantitative analysis of DCFHDA fluorescence found that LPS concentrations of $0.25 \mathrm{EU} / \mathrm{mL}$ to $5 \mathrm{EU} / \mathrm{mL}$ were insufficient to induce oxidative stress in MDM cells after up to 72 hours of exposure (Figure 2[IIA]). However, LTA exposure had a positive effect on ROS generation in a dose and time-dependent manner. A significant increase in ROS was observed following 48 hours of LTA exposure at concentrations 

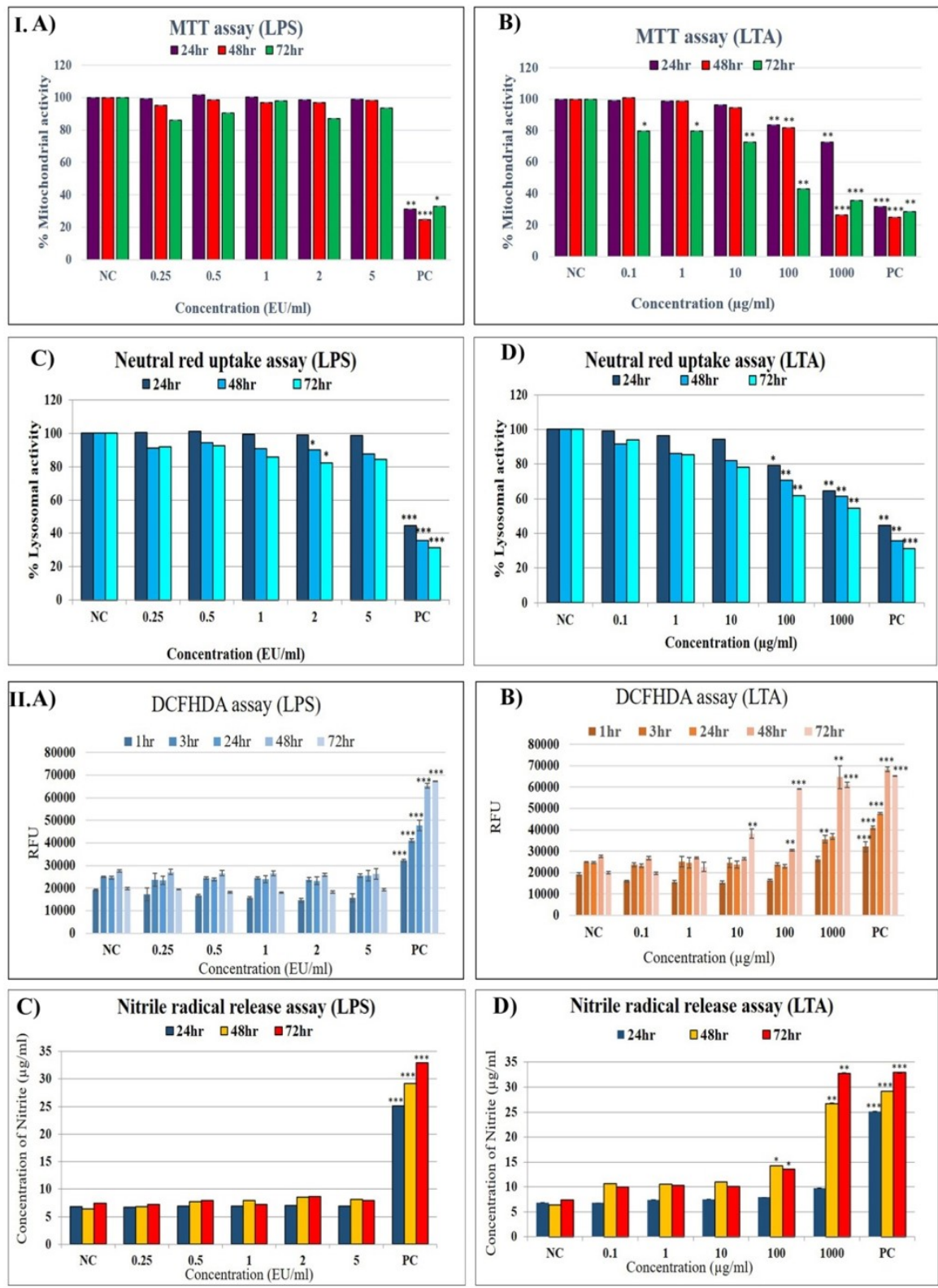

Figure 2: Cytotoxicity analysis. I) MTT and Neutral red uptake assay following exposure to LPS (A, C) and LTA (B, D). Phenol treated cells were used as the positive control. II) ROS and NO release assay after 24,48 and $72 \mathrm{~h}$ exposure to LPS (A, C) and LTA (B, D). Data represent mean $\pm S D, n=3$, Asterisk denotes a statistically significant difference compared to the control group $\left(^{*} p<0.05,{ }^{* *} p<0.01\right.$ and $\left.{ }^{* * *} p<0.001\right)$. https://doi.org $/ 10.6084 / \mathrm{m} 9$. fi gshare.16713160.v1 
of $100 \mu \mathrm{g} / \mathrm{mL}(\mathrm{p}<0.01)$ and $1000 \mu \mathrm{g} / \mathrm{mL}(\mathrm{p}<0.01)$ and after 72 hours of exposure at the same concentrations of $100 \mu \mathrm{g} / \mathrm{mL}(\mathrm{p}<0.001)$ and $1000 \mu \mathrm{g} / \mathrm{mL}$ $(\mathrm{p}<0.001)$. Incubation with the highest concentration of LTA $(1000 \mu \mathrm{g} / \mathrm{mL})$ resulted in a statistically significant production of ROS after 3 hours (22986.6 $\pm 801.30, \mathrm{p}<0.01)$. However, this increase became non-significant after 24 hours $(36928 \pm 1317.5, \mathrm{p}>$ 0.05). An increase in exposure to time to 72 hours resulted in a significant induction of ROS generation, even at the $10 \mu \mathrm{g} / \mathrm{mL}$ concentration of LTA (38224 \pm 2076.9, $\mathrm{p}<0.01$ ) (Figure 2[II- B]).

\section{Nitrile radical release by Griess assay}

Griess assay was used to estimate RNS production in LPS-treated and LTA-treated cells. Figure 2(II-C) shows that there was no stress-induced release of nitrile radicals following LPS exposure for 24 hours, 48 hours, and 72 hours. Graphs of all LPS concentrations are comparable with the results of the untreated control cells. An LTA exposure concentration of 100 $\mu \mathrm{g} / \mathrm{mL}$ resulted in a significant increase in nitrile radical production after 48 hours $(\mathrm{p}<0.05)$ and 72 hours $(p<0.05)$ of exposure. Regarding the difference in LTA concentrations, following 48 hours of LTA exposure, a significant increase in nitrile radical production was found at concentrations of $100 \mu \mathrm{g} / \mathrm{mL}$ (14.21 $\pm 0.0007, \mathrm{p}<0.05)$ and $1000 \mu \mathrm{g} / \mathrm{ml}(26.71 \pm 0.096$, $\mathrm{p}<0.01)$. Following 72 hours of LTA exposure, the concentration of NO produced at an LTA concentration of $100 \mu \mathrm{g} / \mathrm{mL}(13.57 \pm 0.012)$ was similar to the value obtained after 48 hours of exposure to the same concentration. However, at the $1000 \mu \mathrm{g} / \mathrm{mL}$ concentration, a significant increase in the concentration of NO produced was observed $(32.78 \pm 0.08, \mathrm{p}<0.01$; Figure 2[II-D]).

\section{Lysosomal integrity by AO staining}

AO emits red fluorescence from active lysosomes. When there is a loss of lysosomal membrane integrity, lysosomal contents may flow from the vesicles to the cytoplasm. As shown in Figure 3A, it was observed that there was no lysosomal destabilization following 24 hours of exposure to $0.25 \mathrm{EU} / \mathrm{mL}$ to $5 \mathrm{EU} / \mathrm{mL}$ of LPS, with all cellular lysosomes emitting red fluorescence and, therefore, having intact lysosomal membranes. However, exposure of MDM cells to LTA caused a dose-dependent reduction in red fluorescence compared to untreated control cells. The number of green fluorescent cells increased following exposure to LTA concentrations of $100 \mu \mathrm{g} / \mathrm{mL}$ and 1000 $\mu \mathrm{g} / \mathrm{mL}$. A reduction in red fluorescence indicates that the lysosomal membrane was destabilized in LTAtreated cells, as can be seen in Figure 3B (v, vi).

\section{Fluorescence imaging of MMP using JC1} dye

Disruption in cellular MMP was analyzed using a JC1 fluorescent probe following 24 hours of exposure to LPS and LTA. Cells with active MMP emit red fluorescence, while the JC1 dye emits green fluorescence when there is a loss of MMP. It was observed that there was no change in the MMP of MDM cells following exposure to $0.25,1$, and $5 \mathrm{EU} / \mathrm{mL}$ of LPS. Cellular mitochondria were found to be viable with active membrane potential, with the emission of red fluorescence representing the formation of J-aggregates inside the cells (Figure 4A). Low concentrations of LTA $(0.1$ and $10 \mu \mathrm{g} / \mathrm{mL})$ also had no deteriorating effects on MMP. However, 24 hours of exposure to 1000 $\mu \mathrm{g} / \mathrm{mL}$ of LTA resulted in a reduction of red fluorescence an increase of green fluorescence, indicating the loss of MMP, as shown in Figure 4A.

\section{FACS analysis of MMP by DilC1 (5) assay}

In healthy living cells, the maintenance of MMP in a narrow range is crucial for the production of ATP and associated cellular viability. Along with JC1 fluorescent imaging, the present study evaluated the loss of MMP following exposure to LPS and LTA using a DilCI (5) fluorescent probe. It was observed cells exposed to $1 \mathrm{EU} / \mathrm{mL}$ of LPS showed similar fluorescent intensity as the untreated control cells. However, in cells exposed to $2 \mathrm{EU} / \mathrm{mL}$ and $5 \mathrm{EU} / \mathrm{mL}$ concentrations of LPS, the DiIC1 (5) fluorescence shifted towards the left of negative control, indicating a slight reduction in the MMP of treated cells (Figure 4B). The graph of DiIC1 (5) following exposure to 10 $\mu \mathrm{g} / \mathrm{mL}$ and $100 \mu \mathrm{g} / \mathrm{mL}$ of LTA shows similar results to those observed following JC1, namely that the treated cells were viable with active MMP. However, exposure to $1000 \mu \mathrm{g} / \mathrm{mL}$ of LTA induced a loss of MMP in more than $80 \%$ of cells, resulted in a shift in the intensity of DilC1 (5) fluorescence towards that seen in the positive control. As shown in Figure 4B, only $20 \%$ of cells had active MMP that remained comparable with the untreated control cells following exposure to 1000 $\mu \mathrm{g} / \mathrm{mL}$ of LTA.

\section{Lactate dehydrogenase release assay}

A loss of cell membrane integrity and the release of LDH into the extracellular matrix was analyzed using the CyCOUNT LDH release assay. No significant loss of membrane integrity or release of $\mathrm{LDH}$ was observed following 24 hours and 48 hours of exposure to $0.25 \mathrm{EU} / \mathrm{mL}$ to $5 \mathrm{EU} / \mathrm{mL}$ of LPS. When the time of exposure increased to 72 hour, there was a significant increase in LDH release at LPS concentrations 


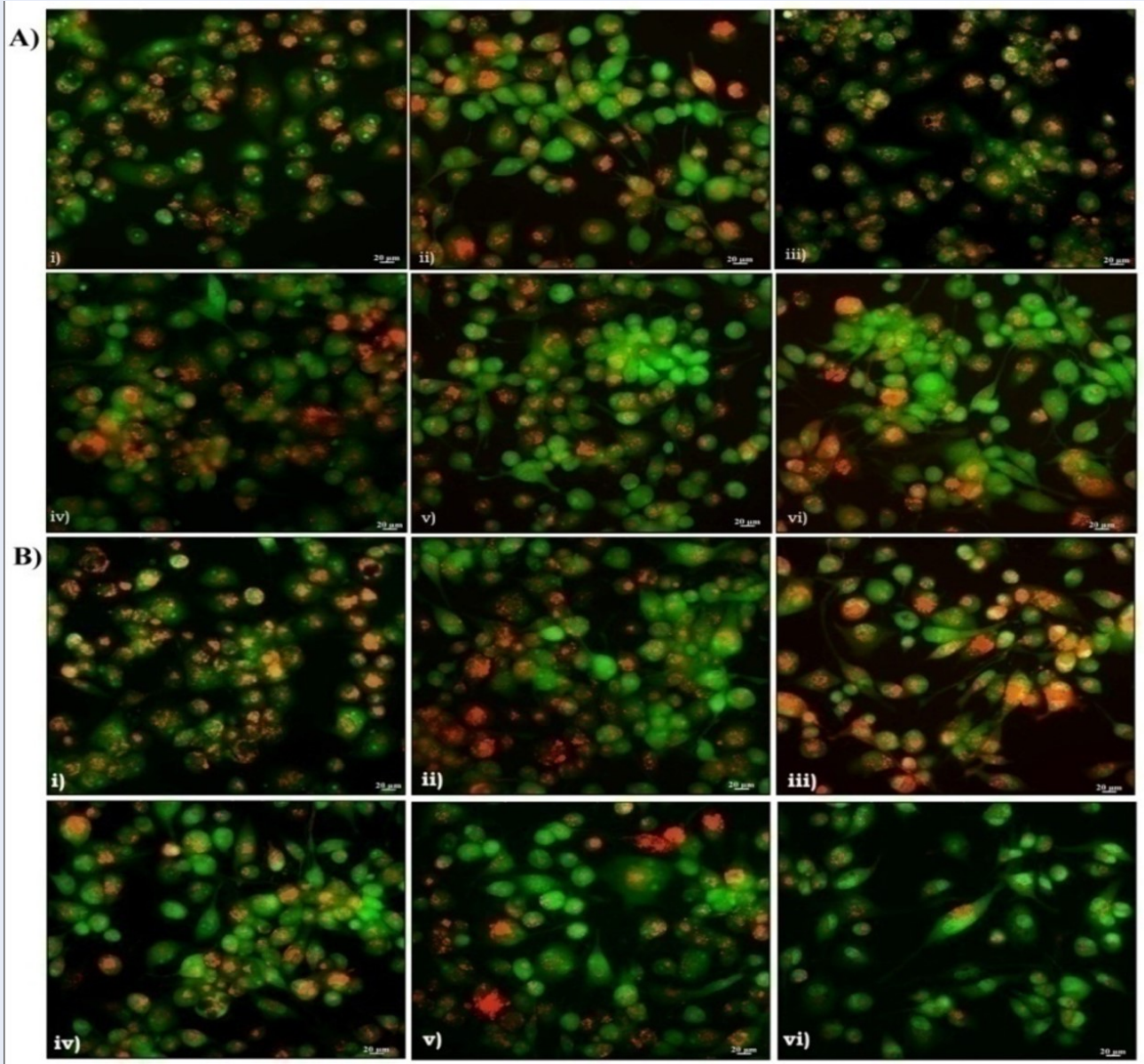

Figure 3: AO staining for analysis of lysosomal integrity. A) Lysosomal membrane integrity after exposure to LPS (i) Control, (ii) LPS $0.25 \mathrm{EU} / \mathrm{ml}$, (iii), LPS $0.5 \mathrm{EU} / \mathrm{ml}$, (iv) LPS $1 \mathrm{EU} / \mathrm{ml}$, (v) LPS $2 \mathrm{EU} / \mathrm{ml}$, (vi) LPS $5 \mathrm{EU} / \mathrm{ml}$; B) Lysosomal membrane integrity after exposure to LTA (i) Control, (ii) LTA $(0.1 \mu \mathrm{g} / \mathrm{ml}$ ), (iii) LTA $1 \mu \mathrm{g} / \mathrm{ml}$, (iv) LTA 10 $\mu \mathrm{g} / \mathrm{ml}$, (v) LTA $100 \mu \mathrm{g} / \mathrm{ml}$, (vi) LTA $1000 \mu \mathrm{g} / \mathrm{ml}$ for 24h. Scale bar $20 \mu \mathrm{m}$. Magnification 20X. Red fluorescenceLysosomes. https://doi.org/10.6084/m9.figshare.16713163.v1

of $2 \mathrm{EU} / \mathrm{mL}(\mathrm{p}<0.05)$ and $5 \mathrm{EU} / \mathrm{mL}(\mathrm{p}<0.05$; Figure 5A). Like LPS, LTA exposure up to concentrations of $10 \mu \mathrm{g} / \mathrm{mL}$ had no significant impact on cell membrane integrity and associated LDH release, regardless of the exposure period. LDH release was observed following 24 hours of exposure to $100 \mu \mathrm{g} / \mathrm{mL}$ of LTA and increased in a time-dependent manner. An LTA concentration $1000 \mu \mathrm{g} / \mathrm{mL}$ was cytotoxic depending on time, showing significant impacts after 24 hours $(\mathrm{p}<0.001)$ and 72 hours $(\mathrm{p}<0.001)$ of exposure (Figure 5B).

\section{Calcein AM/PI assay}

The calcein-AM/PI dual staining method was employed to detect the alive and dead MDM cells following up to 3 days of LPS and LTA with time intervals of 24 hours. As shown in Figure 5C, no sig- nificant difference in the fluorescent intensity following LPS exposure was observed compared to the untreated control. Exposure of LPS to MDM cells did not induce a loss of membrane integrity or increase permeabilization to PI. There was no substantial reduction in calcein-AM signaling even after 24 hours $(3.74 \pm 0.22)$ and 48 hours $(3.59 \pm 0.19)$ of exposure to $5 \mathrm{EU} / \mathrm{mL}$ of LPS. However, a significant reduction in the ratio of calcein-AM to PI fluorescence following 72 hours of exposure to $5 \mathrm{EU} / \mathrm{mL}$ of LPS was observed $(3.18 \pm 0.12, \mathrm{p}<0.01)$. Contrary to exposure to LPS, LTA exposure was toxic, as seen in the other assay results. Exposure to increasing concentrations of LTA resulted in a corresponding decrease in the fluorescence ratio and elicited significant membrane permeabilization in MDM cells. Reduction in the number of live cells was observed after 72 hours of exposure 

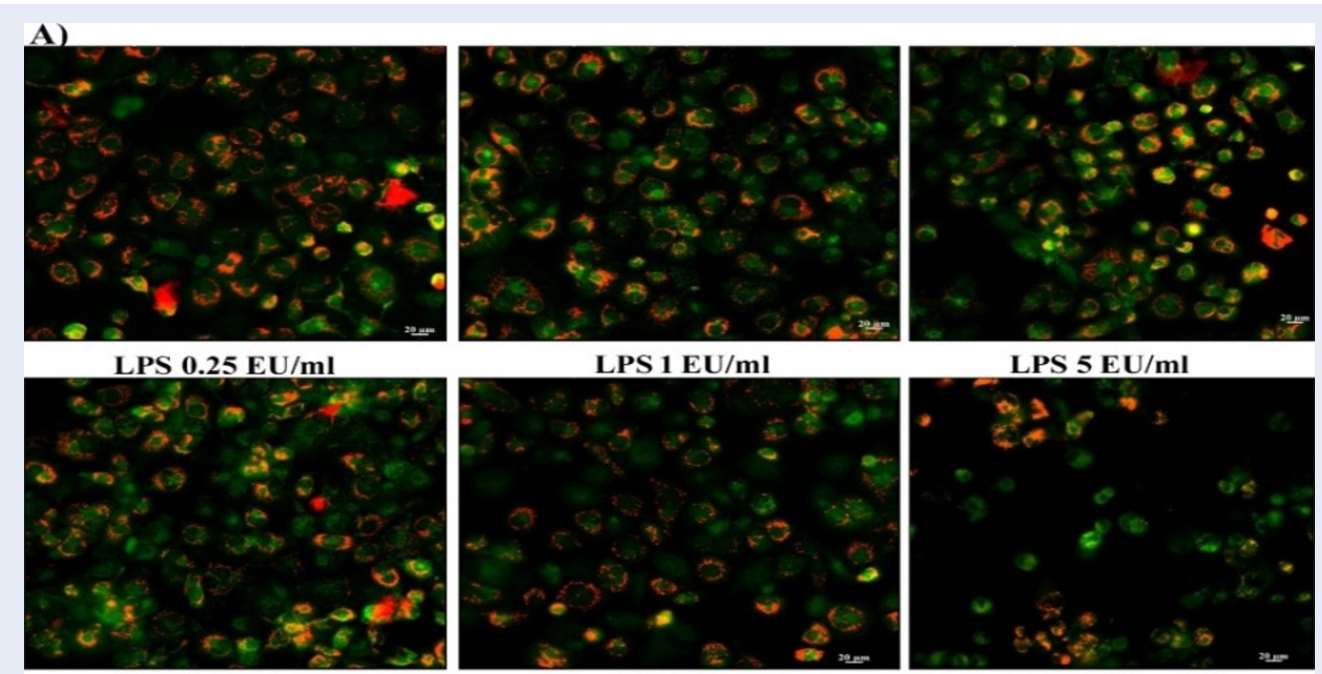

LPS $5 \mathrm{EU} / \mathrm{ml}$
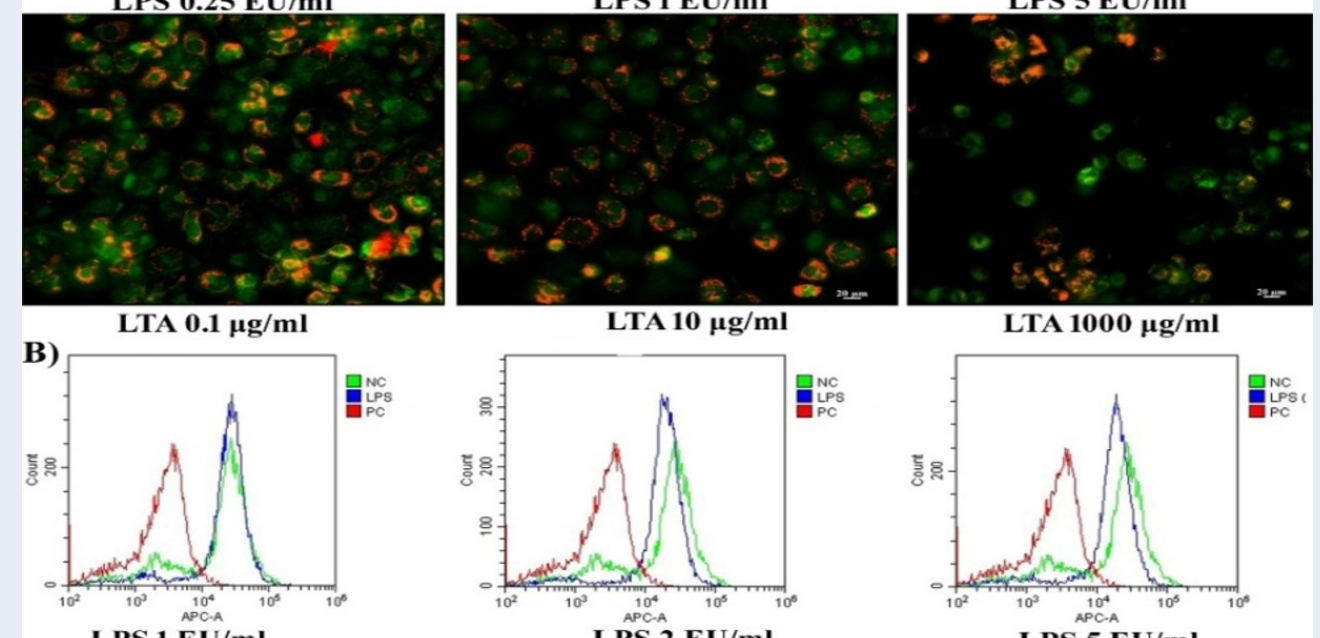

LPS 2 EU/ml

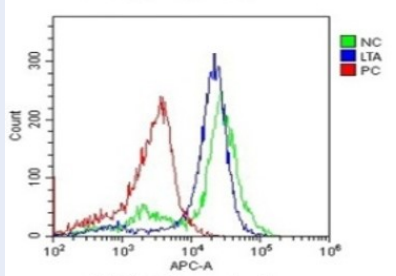

LTA $10 \mu \mathrm{g} / \mathrm{ml}$

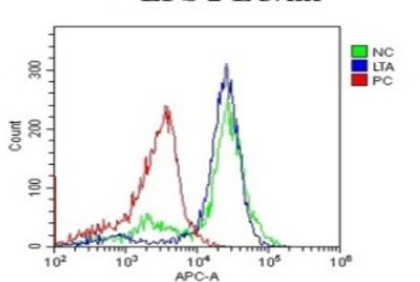

LTA $100 \mu \mathrm{g} / \mathrm{ml}$
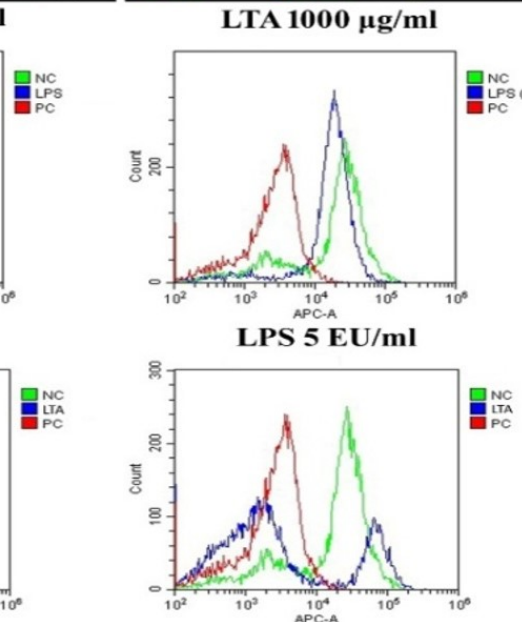

LTA $1000 \mu \mathrm{g} / \mathrm{ml}$

Figure 4: Analysis of mitochondrial membrane potential. A) MMP analysis in MDM cells using JC1 fluorescent probe after exposure with LPS and LTA. Red fluorescence indicates J-aggregates. Scale bar $20 \mu \mathrm{m}$, Magnification 20X. B) FACS analysis in MDM cells using DilC1 (5) fluorescence probe following exposure with LPS and LTA. https: //doi.org/10.6084/m9.figshare.16713169.v1

to $1 \mu \mathrm{g} / \mathrm{mL}$ of LPS. The ratio of live and dead cells following 24 hours and 48 hours of exposure remained comparable with the untreated control. Exposure to 10,100 , and $1000 \mu \mathrm{g} / \mathrm{mL}$ of LTA increased the ratio of PI-positive cells in a time-dependent manner. These results suggest an exponential increase in the number of dead cells in all three exposure periods for LTA. The reduction was significant following 72 hours of exposure for concentrations of $100 \mu \mathrm{g} / \mathrm{mL}$ ( $\mathrm{p}<0.01$ ) and $1000 \mu \mathrm{g} / \mathrm{mL}$ ( $\mathrm{p}<0.001$; Figure 5D). Fluorescent imaging results of the calcein-AM/PI stains are depicted in Figure 5E. Following 24 hours of exposure to $0.25,1$, and $5 \mathrm{EU} / \mathrm{mL}$ of LPS, the majority of calceinAM-stained cells were found to emit green fluorescence. Furthermore, $80 \%$ of cells appeared viable fol- lowing 24 hours of exposure to 0.1 and $10 \mu \mathrm{g} / \mathrm{mL}$ of LTA. However, the number of PI-positive cells appeared to increase following exposure to $1000 \mu \mathrm{g} / \mathrm{mL}$ of LTA.

\section{Annexin V/PI apoptosis assay}

The induction of apoptosis and necrosis in MDM cells was assessed following 24 hours of exposure to LPS and LTA, using annexin V-FITC flow cytometry. From this analysis, it was noted that $89.54 \%$ of cells in the untreated control were unstained and viable. Similarly, more than $85 \%$ of cells were found in the lower left quadrant of the gated population after 24 hours of exposure with 0.25 to $5 \mathrm{EU} / \mathrm{mL}$ of LPS, indicating the absence of apoptotic or necrotic 

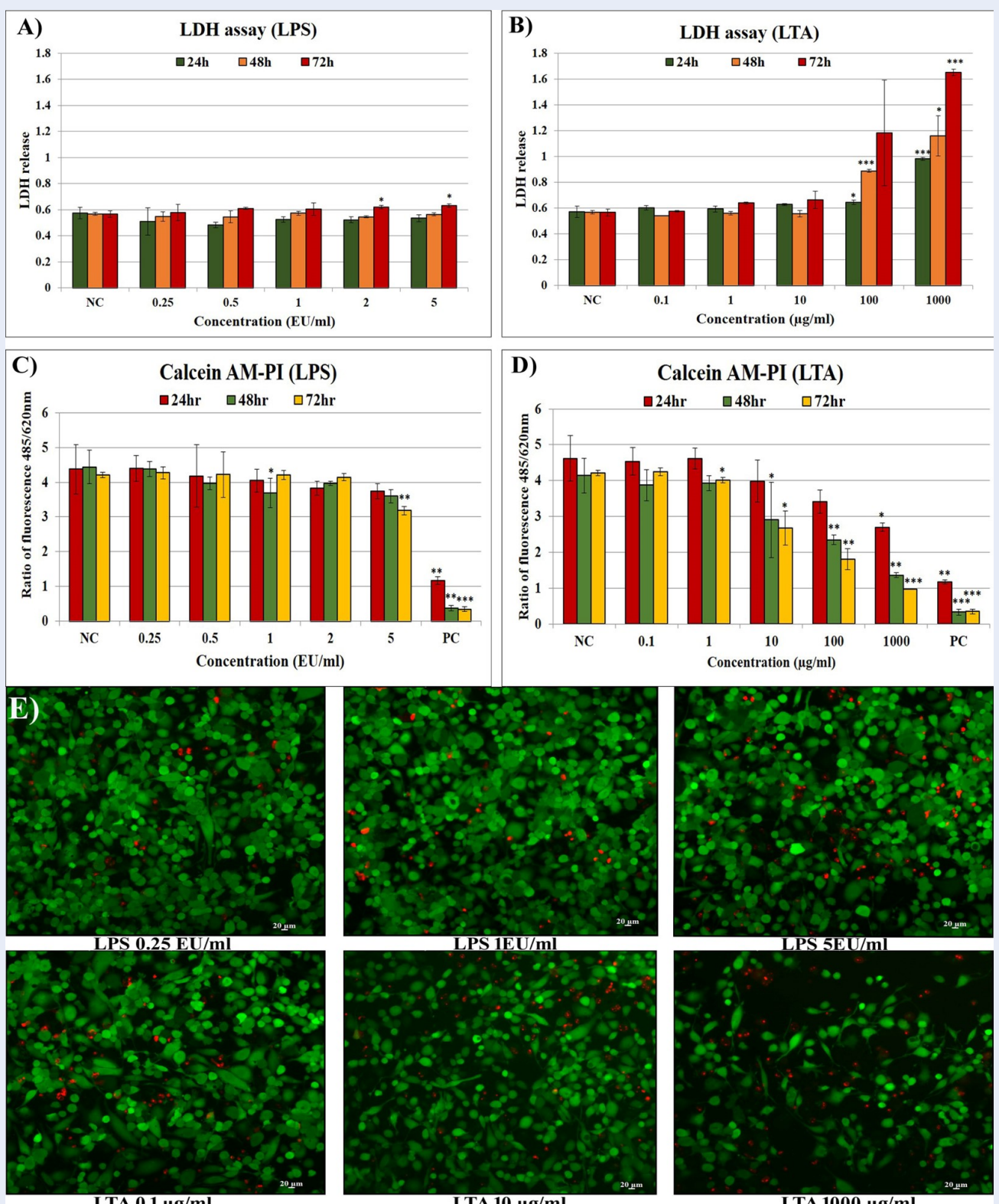

Figure 5: LDH release assay. LDH release in MDM cells following the exposure of LPS (A) and LTA (B) Calcein AM-PI analysis following exposure with LPS (C) and LTA (D). The data represent the mean $\pm S D, n=3$. The asterisk above columns denotes a statistically significant difference compared to the control group $\left({ }^{*} p<0.05,{ }^{* *} p<0.01\right.$ and ${ }^{* * *} \mathrm{p}<0.001$ ). E) Representative fluorescence image of Calcein AM-PI after LPS and LTA exposure for $24 \mathrm{~h}$. Scale bar $20 \mu \mathrm{m}$, Magnification 10X. https://doi.org/10.6084/m9.figshare.16713172.v1 


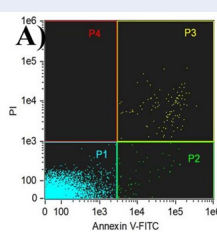

Control

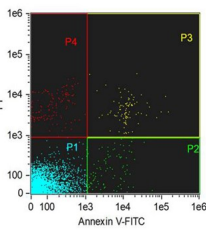

LPS $1 \mathrm{EU} / \mathrm{ml}$

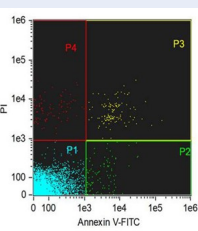

LPS $0.25 \mathrm{EU} / \mathrm{m}$

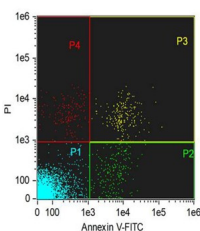

LPS $2 \mathrm{EU} / \mathrm{ml}$

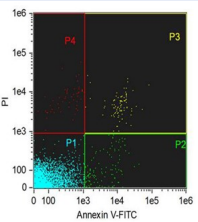

LPS $0.5 \mathrm{EU} / \mathrm{ml}$

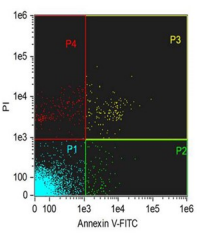

LPS $5 \mathrm{EU} / \mathrm{ml}$

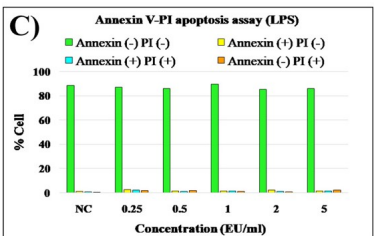

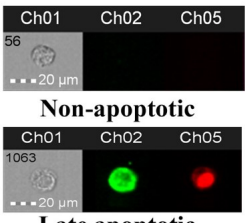

Late apoptotic

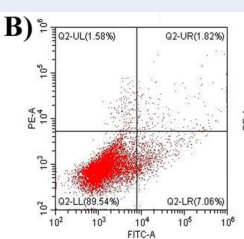

Control

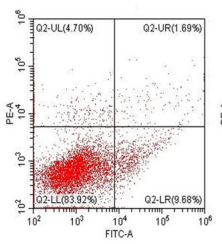

LTA $10 \mu \mathrm{g} / \mathrm{ml}$

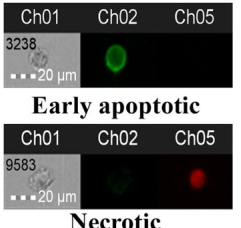

Necrotic

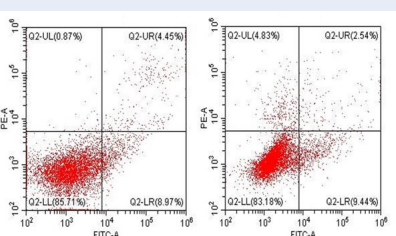

LTA $0.1 \mu g / m \mathrm{l}$

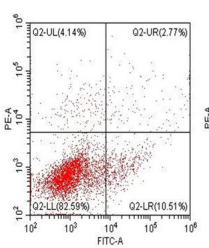

LTA $1 \mu \mathrm{g} / \mathrm{ml}$

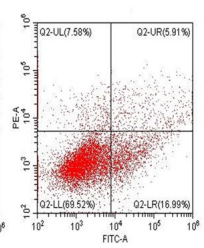

LTA $100 \mu \mathrm{\mu g} / \mathrm{ml}$

LTA $1000 \mu \mathrm{g} / \mathrm{ml}$

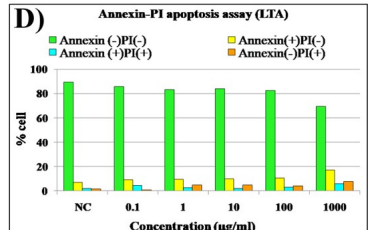

Figure 6: Flow cytometry analysis for apoptotic and necrotic cell death. Apoptosis and necrosis in MDM cells following LPS (A) and LTA (B) exposure for $24 \mathrm{~h}$. Quadrant P1 represent non-apoptotic cells, P2 indicates Annexin V positive early apoptotic cells, P3 indicate double-positive late apoptotic cells and P4 indicate PI-positive necrotic cells. Graphical representation of percentage cells undergoing apoptosis after LPS (C) and LTA (D) exposure. http s://doi.org/10.6084/m9.figshare.16713175.v1

death induction in LPS-treated cells. Less than $2.5 \%$ of cells were found to be in the early (Annexin [+] PI [-]) and late (Annexin [+] PI [+]) apoptotic stages. Even at the highest concentration of LPS, only $1.5 \%$ of cells entered into the necrotic (Annexin [-] PI [+]) stage of cell death (Figure 6A). Exposure for 24 hours to 0.1 to $100 \mu \mathrm{g} / \mathrm{mL}$ of LTA did not induce significant apoptotic or necrotic cell death in MDM cells. Approximately $80 \%$ of treated cells were found to be unstained after up to $100 \mu \mathrm{g} / \mathrm{mL}$ of LTA treatment. However, the proportion of apoptotic and necrotic cells increased in a dose-dependent manner, with the percentage of apoptotic cells increasing from $7 \%$ to $10 \%$ and necrotic cells increasing from $0.8 \%$ to $4 \%$. At a concentration of $1000 \mu \mathrm{g} / \mathrm{mL}$ of LTA, the viable cell number was reduced to $69.52 \%$. It was observed that $16.99 \%$ of cells were in the early apoptotic stage of cell death (Annexin [+] PI [-]), 6\% were in the late apoptotic stage (Annexin [+] PI [+]), and $8 \%$ were in the necrotic stage (Annexin[-] PI [+]; Figure 6B). The percentage of cells in each stage following exposure to LPS and LTA are shown in Figure 6C-D, respectively. The images showing early apoptotic, late apoptotic, and necrotic stages of cell death were visualized in channels 2 and 5 of the flow cytometer as green, red, and green + red fluorescence.

\section{Gene expression by qRT-PCR}

The expression of genes involved in the immune signaling mechanism following LPS and LTA exposure was analyzed using the qRT-PCR technique. NFKB genes that regulate the transcription of inflammatory cytokines, COX2 genes responsible for the synthesis of PGs, and genes encoding IL- $1 \beta$ and TNF- $\alpha$ were quantified following 24 hours of exposure to LPS $(1,2 \mathrm{a}$, and $5 \mathrm{EU} / \mathrm{mL})$ and LTA $(10,100$, and 1000 $\mu \mathrm{g} / \mathrm{mL})$. It was observed that 24 hours of exposure to select concentrations of LPS caused a dose-dependent increase in the expression of $\mathrm{NF} \kappa \mathrm{B}, \mathrm{COX} 2$, and IL$1 \beta$ in MDM cells. The expression of NFKB following exposure to 2 and $5 \mathrm{EU} / \mathrm{mL}$ of LPS was significantly increased $(p<0.01)$. COX2 expression was also significantly increased at the same concentrations $(\mathrm{p}<$ 0.05 ). A 4 to 16 -fold increase in IL- $1 \beta$ expression was observed after exposure to 1,2 , and $5 \mathrm{EU} / \mathrm{mL}$ of LPS. However, the expression of TNF- $\alpha$ was similar to that of the untreated control (Figure 7[A-I]). LTA exposure resulted in a marked increase in the expression of all four inflammation-associated genes. A dosedependent increase in the expression of $\mathrm{NF} \kappa \mathrm{B}, \mathrm{IL}-1 \beta$, and TNF- $\alpha$ was observed following LTA exposure. A 6-fold increase in COX2 expression was observed following exposure to $100 \mu \mathrm{g} / \mathrm{mL}$ of LTA, and a 7 -fold 
A)

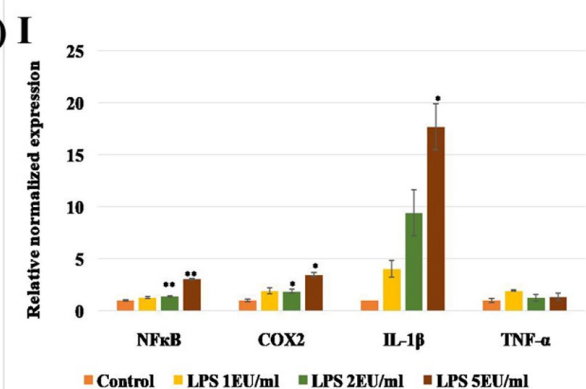

\section{8}

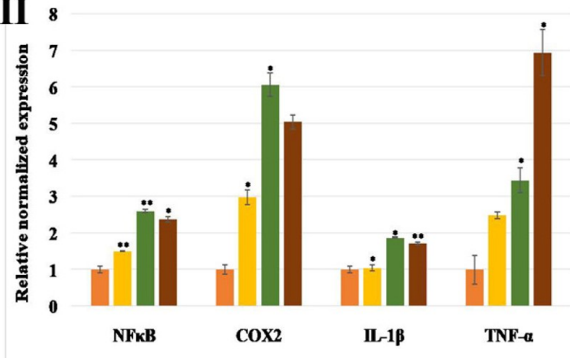

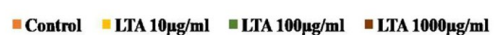

B)

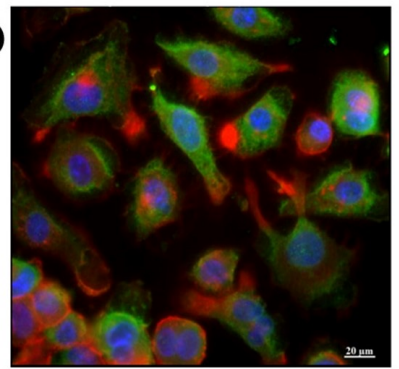

Control

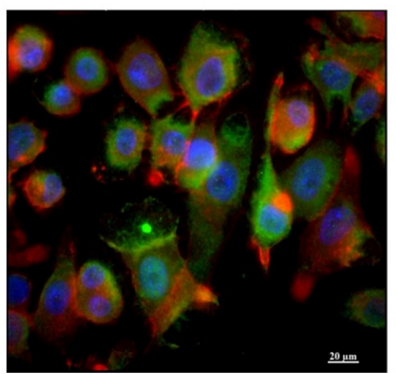

$\mathrm{LPS} 1 \mathrm{EU} / \mathrm{ml}$

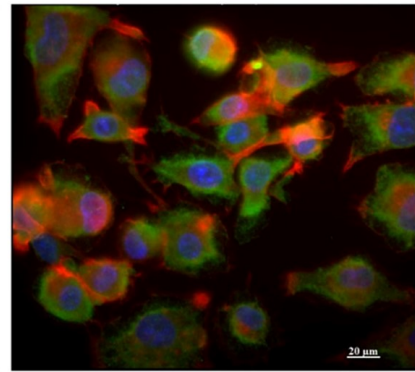

LPS $0.25 \mathrm{EU} / \mathrm{ml}$

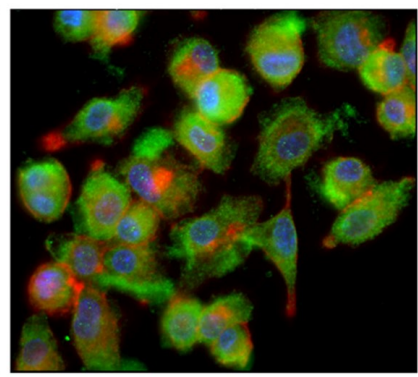

LPS 2EU/ml

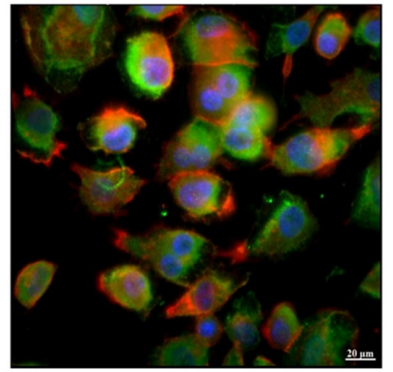

LPS $0.5 \mathrm{EU} / \mathrm{ml}$

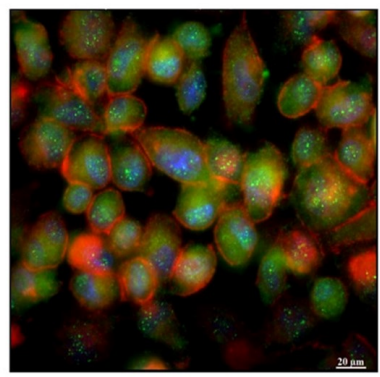

LPS 5EU/ml

Figure 7: Immunotoxicity analysis. A) Gene expression in MDM cells following $24 \mathrm{~h}$ exposure to (I) LPS (1 EU/ml, $2 \mathrm{EU} / \mathrm{ml}, 5 \mathrm{EU} / \mathrm{ml})$ and (II) LTA $(10 \mu \mathrm{g} / \mathrm{ml}, 100 \mu \mathrm{g} / \mathrm{ml}, 1000 \mu \mathrm{g} / \mathrm{ml}$ ) relative to $\beta$-actin (housekeeping gene). Data shown are the means \pm SD from two independent biological replications. The asterisk above columns denotes a statistically significant difference compared to the control group $\left({ }^{*} p<0.05,{ }^{* *} p<0.01\right.$ and $\left.{ }^{* * *} p<0.001\right)$. B) ICC analysis of NFKB activation in MDM cells following $24 \mathrm{~h}$ exposure of LPS. Scale bar $20 \mu \mathrm{m}$, Magnification 40X. http s://doi.org/10.6084/m9.figshare.16713181.v1

increase in TNF- $\alpha$ expression was observed following exposure to $1000 \mu \mathrm{g} / \mathrm{mL}$ (Figure 7A [II]).

\section{Immunocytochemistry for nuclear translo- cation of NFKB}

LPS-induced activation and nuclear translocation of $\mathrm{NF} \kappa \mathrm{B}$ were analyzed by immunocytochemistry analysis (ICC) using a fluorescent microscope (Axioscope). The cells were counterstained with cytopainter (red), and the nuclei were stained with DAPI (blue). An increase in the intensity of green fluorescence of FITClabeled anti-NFKB cells was observed following exposure to 2 and $5 \mathrm{EU} / \mathrm{mL}$ of LPS. In addition, translocation of cytoplasmic NFKB to the nuclei was visible through imaging as green spots inside the nuclei following exposure to $5 \mathrm{EU} / \mathrm{mL}$ of LPS (Figure 7B).

\section{NFkB activation by FACS analysis}

The interaction of LPS and LTA with specific receptors on immune cells activates inflammation signals. The signal transmission involves adaptor molecules and the activation of transcription factors, including NFKB. From the FACS analysis, it was found that LPS and LTA induced NFKB activation in THP-1 cells in a dose-dependent manner. Following the exposure of cells to LPS, activation of NFKB was detected at a rate of $3.0 \%(1 \mathrm{EU} / \mathrm{mL}), 4.97 \%(2 \mathrm{EU} / \mathrm{mL})$, and $13.2 \%$ (5 $\mathrm{EU} / \mathrm{mL}$ ). Following exposure to LTA, the cells showed 


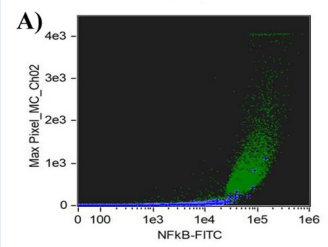

NC/LPS 1EU/ml

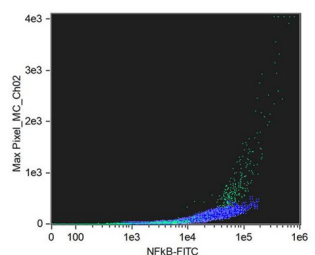

NC/LTA $10 \mu \mathrm{g} / \mathrm{ml}$

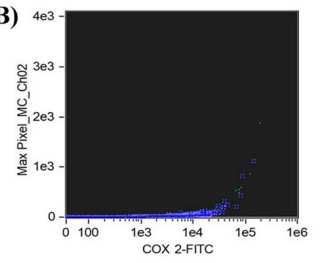

NC/ LPS 1EU/ml

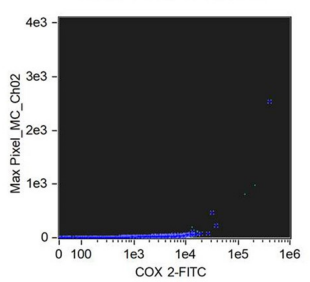

NC/LTA $10 \mu \mathrm{g} / \mathrm{ml}$

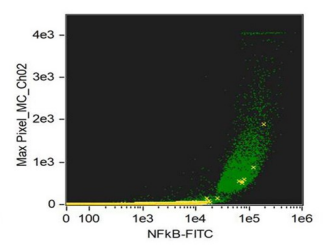

NC/LPS 2EU/ml

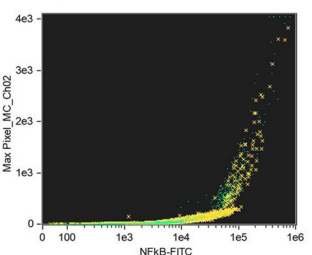

NC/LTA $100 \mu \mathrm{g} / \mathrm{ml}$

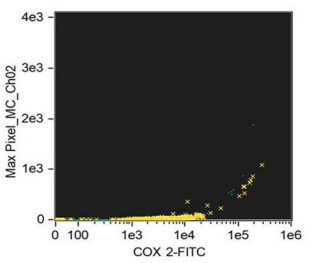

NC/LPS 2EU/m

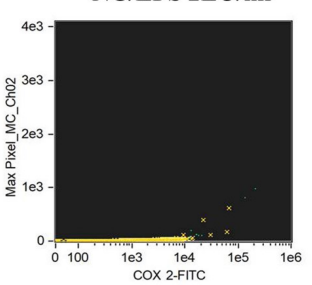

NC/LTA $100 \mu \mathrm{g} / \mathrm{ml}$

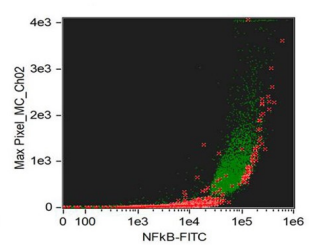

NC/LPS 5EU/ml

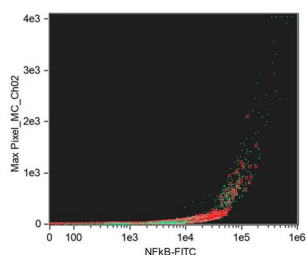

NC/LTA $1000 \mu \mathrm{g} / \mathrm{ml}$

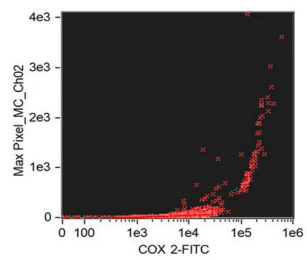

NC/LPS 5EU/ml

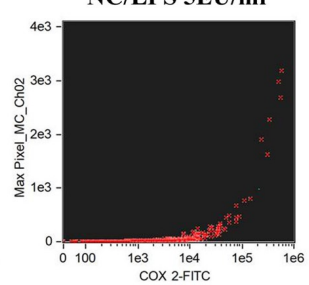

NC/LTA $1000 \mu \mathrm{g} / \mathrm{ml}$

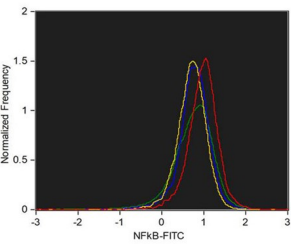

Combined

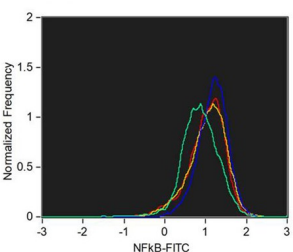

Combined

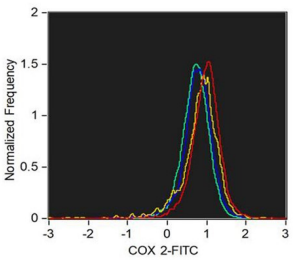

Combined

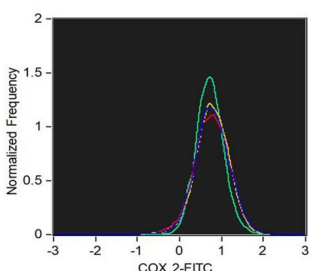

Combined

Figure 8: Analysis of immune signalling. A) FACS analysis of NFKB activation in THP-1cells after LPS and LTA exposure for 24h. B) FACS analysis of COX2 activation in THP-1 cells after LPS and LTA exposure for 24h. https://do i.org/10.6084/m9.figshare.16713190.v1

NFKB activation rates of $29.8 \%(10 \mu \mathrm{g} / \mathrm{mL}), 52.8 \%$ $(100 \mu \mathrm{g} / \mathrm{mL})$, and $82.3 \%(1000 \mu \mathrm{g} / \mathrm{mL}$; Figure 8A).

\section{COX2 activation by FACS analysis}

COX is an enzyme involved in the synthesis of PGs. PGs act as mediators of pyrogenic responses in the CNS. It was observed that $5 \mathrm{EU} / \mathrm{mL}$ of LPS induced significant activation of COX2 in treated cells. However, compared to untreated control cells, the percentage of cells exhibiting COX2 activation was low after exposure to 1 and $2 \mathrm{EU} / \mathrm{mL}$ of LPS 1 . Exposure to LTA $(10,100$, and $1000 \mu \mathrm{g} / \mathrm{mL})$ did not induce COX2 signals in treated cells compared to untreated control cells. As shown in Figure 8B, there was no characteristic shift of fluorescence towards the right of the negative control in treated cells following LTA exposure.

\section{DISCUSSION}

Pyrogenic contamination in parenteral products may cause moderate to severe health complications in humans and animals. Activation of immune cells by exogenous pyrogens leads to the induction of inflammation and the release of pyrogenic cytokines. Pyrogenic cytokines such as IL- $1 \beta$, IL- 6 , and TNF- $\alpha$ are mediators of fever and febrile reactions in humans. During pyrogenic interaction, PGs are released from the thermoregulatory center of the hypothalamus and are associated with the induction of fever and febrile reactions ${ }^{\mathbf{1 0}}$. Immune cells, particularly monocytes and macrophages, are the key mediators of the innate immune system and are involved in the phagocytosis and the elimination of foreign particles. Depending upon the inflammatory response, monocytes may 
differentiate into macrophages and migrate to various organs and tissues. Loss of activity or death of these monocytes and macrophages negatively affects the normal homeostasis of the immune system, leading to serious human health issues. LPS and LTA are the most common bacterial pyrogenic contaminators seen in biological preparations. For assessing the cytotoxicity of biological and chemical toxicants, understanding the normal function of cellular organelles is essential. Since mitochondria function as the powerhouse of a cell, any change in membrane potential or in the oxidation-reduction pathway may result in a loss of cell viability. In the present study, THP-1 cells served as a model for monocytes and MDM cells. Inflammation usually induces monocytes to differentiate to the characteristic M1 phenotype, whereas anti-inflammatory signals stimulate differentiation into the M2 phenotype. Therefore, monocyte differentiation alters the cell's morphological characteristics, adherence properties, and inflammatory responses $^{11}$.

MTT and neutral red assays were carried out to assess organelle function regarding mitochondrial reduction potential and lysosomal dye uptake. It was observed that regardless of concentration, LPS had no significant effect on the mitochondrial oxidationreduction potential and lysosomal phagocytic potential of MDM cells. Morphological characteristics observed under rhodamine-phalloidin and Giemsa staining also indicated a non-toxic impact of LPS on cell morphology and membrane integrity. Similar to those observations, it was also found that LPS was non-cytotoxic to human airway epithelial cells at low concentrations. Previous studies have noted that LPSmediated cytotoxicity in monocytes required longterm exposure for a period of more than 72 hours ${ }^{12}$. Pyrogenic responses by gram-positive bacteria rely on the LTA component of their cell walls. In the present study, LTA, acquired from Bacillus subtilis, displayed cytotoxicity in a dose and time-dependent manner. There was a significant loss of mitochondrial and lysosomal activity in MDM cells within 48 to 72 hours of LTA exposure. At higher concentrations of LTA exposure, cellular actin filament organization became disrupted and detached from the culture plate. Rounding of cells and the loss of the characteristic macrophage extensions indicated impairment of the actin filaments and membrane destabilization. The presence of serum in cell culture media has been previously reported as playing a prominent role in the cytotoxicity of LTA derived from Streptococcus pyogens in mouse fibroblast monolayers. As per the studies of
Leon and Panos, the toxic effect of LTA has been reported to be associated with the inhibition of collagen synthesis and cell membrane destabilization ${ }^{13}$.

Free radicals are highly reactive, unstable atomic species that contain an unpaired electron in their outermost orbital. The generation and propagation of free radicals is linked to various diseases and aging in humans. Inflammation and free radical generation are both associated with exogenous pyrogen exposure and can lead to apoptotic or stress-induced death of immune cells. Spitzer et al. (2020) reported oxidative stress induction in rodent mammary glands after in vivo administration of $E$. Coli LPS. LPS can activate superoxide dismutase 1 (Sod1) and NQO1 enzymes to increase the release of $\mathrm{H}_{2} \mathrm{O}_{2}$ inside the cell ${ }^{\mathbf{1 4}}$. In the present study, the selected concentrations of LPS were insufficient to cause any free radical generation and oxidative stress in MDM cells, even after 72 hours of exposure. There have been reports of timedependent death of mixed neuronal-glial cells by LTA derived from Staphylococcus aureus. However, the proliferation of glial and astrocyte cells has also been reported after 72 hours of incubation with LTA, with it being noted that short-term exposure to LTA was insufficient to induce direct cellular toxicity in neuronal cells. The coordinated release of inflammatory cytokines from astrocytes and nitrile radicals from microglia leads to stress-induced neuronal cell death. Previous studies have found evidence that nitrile radicals and the associated superoxide anion production play significant roles in the LTA-mediated toxicity of neuronal cells ${ }^{15}$. The present study observed that LTA induced time and dose-dependent hydroxyl and nitrile radical generation in MDM cells. Long-term exposure to as little as $10 \mu \mathrm{g} / \mathrm{mL}$ of LTA caused a significant rise in the hydroxyl radical production in MDM cells. Oxidative stress ultimately leads to cellular death when ROS production exceeds the resistance provided by the antioxidant defense mechanism of cells. Previous studies have reported that LTA is capable of inducing oxidative stress in heart-derived H9c2 myogenic cells, with a significant reduction in the expression of the antioxidant enzymes superoxide dismutase, catalase, and glutathione peroxidase seen in the cells. LTA also activates inflammatory pathways through the induction of $\mathrm{p} 38$ and the JNK pathway ${ }^{16}$. MMP is maintained in a narrow range to keep the critical cellular processes of cellular respiration and ATP generation functioning. Loss of MMP results in a sudden drop in cellular ATP level and, consequently, cell death. The present study found that the MMP of THP-1 cells was not affected by 72 hours of exposure to LPS concentrations of 0.25 to $5 \mathrm{EU} / \mathrm{mL}$. 
The orange-red fluorescence observed in JC1 staining also confirmed the presence of active MMP in LPStreated MDM cells. The selected concentrations of LPS were, therefore, insufficient to cause mitochondrial dysfunction and reduction in MMP. However, mitochondrial fragmentation, metabolic shifts, ROS production, and increased MMP in microglial cells following 24 hours of exposure to LPS have been previously associated with $\mathrm{NFKB}$ and MAPK-activated metabolic reprogramming in microglial cells. The pro-inflammatory state of these microglial cells has been associated with mitochondrial fission and increased production of ROS and RNS ${ }^{17}$. Mitochondrial dysfunction associated with bacterial sepsis is a critical event in inflammatory injury and cell death. In the present study, LTA exposure led to a dosedependent loss of MMP in THP-1 cells. The coordinated action of the ATP synthase complex, cytochrome $\mathrm{c}$, and membrane anchoring proteins is involved in MMP regulation in cells. Toll-like receptor 2 (TLR2) mediated signaling, which is associated with bacterial sepsis, plays a role in intracellular $\mathrm{H}_{2} \mathrm{O}_{2}$ and mitochondrial $\mathrm{O} 2$ production. It has been reported that LTA can induce the release of cytochrome $c$ and can, therefore, be associated with the loss of MMP in $\mathrm{H} 9 \mathrm{c} 2$ cells ${ }^{18}$. ATP depletion and the ensuing associated acidosis, the release of cytochrome c, and the dysfunction of electron transferring protein complexes in the electron transport chain can create instability in MMP.

Lysosomes mediate autophagy, exocytosis, and degradation of cellular components and are necessary for the proper functioning of immune cells. Lysosomes act as the crossroad for various metabolic and catabolic functions. As lysosomes have an essential role in cell survival, previous research has focused on lysosomes as therapeutic targets for multiple diseases. Lysosomal membrane destabilization and the subsequent release of hydrolytic enzymes into the cytosol activates the lysosome-dependent death pathway. The present study observed that LPS concentrations up to $5 \mathrm{EU} / \mathrm{mL}$ did not induce lysosomal membrane destabilization. LPS interaction with TLR4 receptors activates signaling through TRIF (TIR-domaincontaining adaptor-inducing interferon- $ß$ ), resulting in the apoptotic death of macrophages principally through lysosomal dysfunction ${ }^{19}$. In the present study, lysosomal membrane destabilization was observed using AO staining following 24 hours of exposure to LTA. The results correlate with those seen in the neutral red assay, where the phagocytic potential of lysosomes was significantly affected in a dose and time-dependent manner. Bacterial exotoxins form membrane pores when exposed to acidic pHs, which, in turn, drives these toxins into the lysosomes. Exotoxin-mediated oxidative stress releases ROS and RNS. Diffusion of these ROS into lysosomes results in lipid peroxidation and membrane destabilization. Lysosomal membrane permeabilization is considered the primary or secondary route of cell death executed via apoptotic or necrotic mechanisms ${ }^{20}$. The present study investigated the ability of endotoxins and exotoxins to induce apoptotic or necrotic death using the dual fluorescent probe annexin V/PI. LPS and LTA were found to induce apoptosis in THP-1 MDM cells. Klein et al. (2001) reported the LPS-mediated inhibition of apoptosis in human neutrophils through the extracellular regulated kinase pathway. Recent studies have also found no significant indication of phosphatidylserine externalization following exposure to LPS in THP-1 cells ${ }^{21}$. In the present study, the highest concentration of LTA was found to cause apoptotic cell death in THP-1 cells. A recent study examining LTA-induced apoptosis in microglial cells through the augmented activation of the inducible nitric oxide synthase enzyme supports this finding ${ }^{22}$.

Interaction of LPS with TLR4 present on monocytes and macrophages initiates various inflammatory signaling pathways. Transduction of TLR4 signaling is dependent on adaptor molecules such as MyD88 and TRIF-TRAM. TLR4 signaling via adaptor molecules initiates pro-inflammatory gene expression. NFKB is the most recognized and studied transcription factor involved in LPS-TLR4 inflammation signaling. Phosphorylation of the p65 subunit of NFKB plays a crucial role in the activation, translocation, and specificity of downstream signaling. Translocation of cytosolic NFKB to the nucleus is required for the active expression of the pro-inflammatory cytokine genes. However, phosphorylation of p65 and, therefore, the translocation of NFKB depends on the concentration and strength of LPS-TLR4 binding ${ }^{23}$. In the present study, immunocytochemistry analysis of MDM cells following LPS treatment showed a dosedependent increase in NFKB activation. Therefore, LPS, even at nanogram concentrations, is capable of inducing NFKB translocation in MDM cells. Furthermore, the present study found that LPS interacts with TLR and IL-1 superfamily receptors to enable the transduction of signals to immune cells. The IL-1 family of cytokines convey inflammatory signals through MyD88, IRAK, IRAK2, and TRAF6 adaptor molecules for the activation of NFKB. LPS utilizes a similar pathway in THP-1 cells. LPS-mediated NFKB activation induces the production and release of IL$1 \beta$, IL- 6 , and TNF- $\alpha$, eventually leading to a pyrogenic response in humans ${ }^{24}$. 
Inflammation induced by LTA occurs following a cascade of phosphorylation and dephosphorylation of kinase enzymes in immune cells. LTA can induce the expression of nitric oxide synthase enzyme (iNOS) and the subsequent release of NO radicals in macrophages. Expression of iNOS in macrophages is linked with protein kinase C-mediated NFKB activation $^{25}$. Instead of TLR4 in LPS inflammation, LTA transmits inflammatory signals via TLR2 receptors. In vivo studies, using mice models, conducted with LTA derived from Streptococcus pneumonia demonstrated the role of TLR2-mediated activation in neutrophil influx and inflammatory cytokine release ${ }^{26}$. LTA-TLR2 receptor interaction in macrophage cells activates the tyrosine kinase, PI3K/Akt, and p38 MAPK signaling pathways. Activated kinases can cause a marked increase in NF $\kappa \mathrm{B}-$ specific DNA-protein complex formation. DNAprotein complex formation is an indicator of translocated $\mathrm{NF} \kappa \mathrm{B}$, which, in turn, promotes the transcription of iNOS and pro-inflammatory cytokine genes ${ }^{27}$. The present study detected a dose-dependent activation of NF $\kappa$ B in THP- 1 cells exposed to LTA, suggesting a possible immunotoxic potential of bacterial exotoxins in human monocytes.

Pathogenic contamination during medical procedures can lead to multi-organ failure and death in patients due to septic shock. Septic shock is initiated preliminarily as inflammation, followed by the activation of $\mathrm{NF} \kappa \mathrm{B}$ and COX2. Previous studies have reported COX2 activation following exposure to LPS in mouse transformed Clara cells ${ }^{28}$, RAW264.7 macrophages ${ }^{29}$, IEC-6 cells ${ }^{30}$, and human neutrophils ${ }^{31}$. COX2 expression induces multiple responses in different cells. Reports of COX2 activation strongly support LPS-induced immune activation in various cell types. There are various adaptor molecules for COX2 activation following LPS exposure. COX2 activation involves the phosphorylation of MAPK proteins, JNK, p38, and/or ERK, and the activation of Tpl2-dependent CREB and NF $\kappa$ B. COX2 activation eventually leads to the release of PGE2, Thromboxane A2, and pro-inflammatory cytokines. Expression of $\mathrm{NF} \kappa \mathrm{B}, \mathrm{COX} 2$, and inflammatory cytokines in THP-1 cells following LPS exposure suggests the potential for low concentrations of LPS to activate the immune response in THP-1 cells. However, the same low concentrations do not show a direct cytotoxic effect. Similar to LPS, LTA also induced increased expression of COX2 in THP-1 cells. However, the present study failed to identify specific activations of COX2 signals in both LPS and LTA-treated cells. LTA can interact with the CD14 receptor and activate NF $\kappa$ B-mediated inflammation signaling. Neuronal inflammation induced by bacterial toxins has been reported in rat cortical neuronal cells. It has also been previously reported that LTA can activate COX2 and PGE2 synthesis through PTK, PC-PLC, PI-PLC, and ERK pathways ${ }^{32}$. Similarly, cytosolic phospholipase A2 (cPLA2), COX-2, PGE2, and IL-6 have been found to be elevated in LTA-exposed human tracheal smooth muscle cells. LTA interacts with TLR2 receptors and activates NF $\kappa \mathrm{B}$ through MyD88, PI3K, Rac1, Akt, and MAPK pathways, ultimately resulting in inflammation signaling ${ }^{33}$.

Even though the in vitro system interacts and responds to pyrogenic contaminations, results of in vitro system studies are not comparable with those of in vivo system studies, as cancerous cell lines, such as THP-1, are somewhat resistant to toxic interactions with LPS and LTA. The concentrations of LPS that can cause severe life-threatening reactions in an in vivo system are non-toxic to THP-1 and MDM cells. Similarly, concentrations of LTA above $10 \mu \mathrm{g} / \mathrm{mL}$ can induce a direct toxic response to THP-1 cells. The interaction of cells in an in vitro system differs from the interaction of cells, organs, and systems of living subjects during an in vivo inflammatory reaction. Considering these limitations, the present study highlights that selective inhibitors of $\mathrm{NF} \kappa \mathrm{B}, \mathrm{COX} 2$, and pyrogenic cytokines may be promising factors for treating and preventing pyrogen-induced episodes of fever and febrile reactions in humans.

\section{CONCLUSIONS}

LPS and LTA are the most potent pyrogens of bacterial origin. LPS and LTA, even at nanogram concentrations, are capable of inducing a pyrogenic response in humans. Pyrogenic cytokines such as IL$1 \beta$, IL- 6 , and TNF- $\alpha$ synergistically act at the thermoregulatory center of the hypothalamus and induce fever and febrile reactions. The present study investigated the cellular and immunological response of THP-1 cells after exposure to LPS and LTA. The selected concentrations of LPS were insufficient to cause direct cytotoxicity to THP-1 and MDM cells. However, LTA exposure led to a significant loss of organelle function and membrane integrity in a dose and time-dependent manner. Free radical generation, lysosomal destabilization, and the induction of apoptotic cell death are the principal factors behind LTAmediated toxicity in monocytes. The expression of genes involved in the inflammatory pathway and pyrogenic cytokines were augmented in both LPS and LTA-treated cells. The present study found that even 
nanogram concentrations of LPS and LTA can cause immune activation in THP-1 and MDM cells without overt cytotoxicity. An interconnected cellular and cytokine signaling network is, therefore, necessary to elicit a profound immune response in a living system.

\section{ABBREVIATIONS}

AO: Acridine Orange

CCCP: cyanide 3-chlorophenylhydrazone

CNS: central nervous system

COX: cyclooxygenase

DCFH-DA: $2^{\prime} 7^{\prime}$-dichlorofluorescein diacetate

DiIC1(5): 1, 1' $, 3,3,3^{\prime}, 3^{\prime}$-hexamethylindodicarbo-

cyanine iodide

E. Coli: Escherichia coli

FITC: Fluorescin isothiocyanate

IL-1 $\beta$ interleukin-1beta

IL-6: interleukin-6

JC1: 5,5',6,6'-tetrachloro-1,1',3,3'-tetraethylbenzimi-

dazolylcarbocyanine iodide

LDH: Lactate Dehydrogenase

LPS: Lipopolysaccharides

LTA: Lipoteichoic acid

MDMs: monocyte-derived macrophages

MMP: Mitochondrial membrane potential

MTT: 3-(4,5-dimethylthiazol-2-yl)-2,5-

diphenyltetrazolium bromide

NFkB: nuclear factor-kappa b

PG: prostaglandin

PI: Propidium Iodide

PMA: Phorbol 12-myristate 13-acetate

POA: pre-optic area of the anterior hypothalamus

PS: Phosphatidyl serine

qRTPCR: Quantitative real-time polymerase chain reactions

RNS: Reactive nitrogen species

ROS: Reactive oxygen species

TNF- $\alpha$ : tumor necrosis factor-alpha

\section{ACKNOWLEDGMENTS}

The authors wish to express their thanks to the Director and Head, Biomedical Technology Wing, Sree Chitra Tirunal Institute for Medical Sciences and Technology, Trivandrum, Kerala, India, for their support and for providing the infrastructure to carry out this work. Prajitha thanks the Council of Scientific and Industrial Research, New Delhi, for the SRF Fellowship.

\section{AUTHOR'S CONTRIBUTIONS}

Mohanan: Corresponding author: conception, design of the study, analysis and interpretation of data, critical revision and final approval.

Prajitha: Acquisition of data, drafting, interpretation of data.

All authors read and approved the final manuscript.

\section{FUNDING}

There is no funding from outside agencies. The infrastructure support is provided by the parent Institute.

\section{AVAILABILITY OF DATA AND MATERIALS}

The authors declared that the research data referred correctly cited in the manuscript's reference section. All the raw data are available with the parent institute.

\section{ETHICS APPROVAL AND CONSENT TO PARTICIPATE}

Ethical approval is not applicable since the present work is fully an in vitro work. All experiments are in vitro in nature; the consent part from the subject is not applicable in the study.

\section{CONSENT FOR PUBLICATION}

All the authors agreed to submit the manuscript in the journal. The same has approved by the parent Institute.

\section{COMPETING INTERESTS}

The authors declare that they have no competing interests.

\section{REFERENCES}

1. Das REG, Brügger P, Patel M, Mistry $Y$, Poole S. Monocyte activation test for pro-inflammatory and pyrogenic contaminants of parenteral drugs: test design and data analysis. Journal of Immunological Methods. 2004;288(1-2):165-77. PMID: 15183094. Available from: 10.1016/j.jim.2004.03.002.

2. Garrana R, Mohangi G, Malo P, Nobre M. Leakage of microbial endotoxin through the implant-abutment interface in oral Implants: an in vitro study. BioMed Research International. 2016;2016:9219071. PMID: 28127552. Available from: $10.1155 / 2016 / 9219071$.

3. Walter EJ, Hanna-Jumma S, Carraretto M, Forni L. The pathophysiological basis and consequences of fever. Critical Care (London, England). 2016;20(1):200. PMID: 27411542. Available from: 10.1186/s13054-016-1375-5.

4. Anochie IP. Mechanisms of fever in humans. International Journal of Microbiology and Immunology Research. 2013;2(5):37-43.

5. Sobolewski C, Cerella C, Dicato M, Ghibelli L, Diederich M. The role of cyclooxygenase-2 in cell proliferation and cell death in human malignancies. International Journal of Cell Biology. 2010;2010:215158. PMID: 20339581. Available from: 10.1155/ 2010/215158.

6. Quan N, Whiteside M, Herkenham M. Cyclooxygenase 2 mRNA expression in rat brain after peripheral injection of lipopolysaccharide. Brain Research. 1998;802(1-2):189-97. PMID: 9748570. Available from: 10.1016/S0006-8993(98) 00402-8. 
7. Cao C, Matsumura K, Yamagata K, Watanabe $Y$. Induction by lipopolysaccharide of cyclooxygenase-2 mRNA in rat brain; its possible role in the febrile response. Brain Research. 1995;697(1-2):187-96. PMID: 8593576. Available from: 10. 1016/0006-8993(95)00839-I.

8. Dlugosz E, Basalaj K, Zawistowska-Deniziak A. Cytokine production and signalling in human THP-1 macrophages is dependent on Toxocara canis glycans. Parasitology Research. 2019;118(10):2925-33. PMID: 31396715. Available from: 10.1007/s00436-019-06405-8.

9. Sokolova TM, Poloskov VV, Shuvalov AN, Rudneva IA, Timofeeva TA. Signal Immune Reactions of Macrophages Differentiated from THP-1 Monocytes to Infection with Pandemic H1N1PDM09 Virus and H5N2 and H9N2 Avian Influenza A Virus. Bulletin of Experimental Biology and Medicine. 2018;164(5):636-40. PMID: 29577197. Available from: 10. 1007/s10517-018-4048-3.

10. Dinarello CA. Infection, fever, and exogenous and endogenous pyrogens: some concepts have changed. Journal of Endotoxin Research. 2004;10(4):201-22. PMID: 15373964.

11. Lund ME, To J, O'Brien BA, Donnelly S. The choice of phorbol 12-myristate 13-acetate differentiation protocol influences the response of THP-1 macrophages to a pro-inflammatory stimulus. Journal of Immunological Methods. 2016;430:6470. PMID: 26826276. Available from: 10.1016/j.jim.2016.01. 012.

12. Liu $X$, Yin S, Chen $Y$, Wu Y, Zheng W, Dong H, et al. LPSinduced proinflammatory cytokine expression in human airway epithelial cells and macrophages via NF- $\kappa$ B, STAT3 or AP-1 activation. Molecular Medicine Reports. 2018;17(4):5484-91. PMID: 29393460. Available from: 10.3892/mmr.2018.8542.

13. Leon $\mathrm{O}$, Panos $C$. Cytotoxicity and inhibition of normal collagen synthesis in mouse fibroblasts by lipoteichoic acid from Streptococcus pyogenes type 12 . Infection and Immunity. 1983;40(2):785-94. PMID: 6341248. Available from: 10.1128/ iai.40.2.785-794.1983.

14. Spitzer AJ, Tian Q, Choudhary RK, Zhao FQ. Bacterial endotoxin induces oxidative stress and reduces milk protein expression and hypoxia in the mouse mammary gland. Oxidative Medicine and Cellular Longevity. 2020;2020:3894309. PMID: 32273941 . Available from: 10.1155/2020/3894309.

15. Kinsner A, Pilotto V, Deininger S, Brown GC, Coecke S, Hartung $T$. Inflammatory neurodegeneration induced by lipoteichoic acid from Staphylococcus aureus is mediated by glia activation, nitrosative and oxidative stress, and caspase activation. Journal of Neurochemistry. 2005;95(4):1132-43. PMID: 16144539. Available from: 10.1111/j.1471-4159.2005.03422.x.

16. Gutiérrez-Venegas $G$, Fernández-Rojas $B$, Rosas-Martínez $M$, Sánchez-Carballido MA. Rutin Prevents LTA Induced Oxidative Changes in H9c2 Cells. Preventive Nutrition and Food Science. 2020;25(2):203-11. PMID: 32676472. Available from: 10.3746/pnf.2020.25.2.203.

17. Nair S, Sobotka KS, Joshi P, Gressens P, Fleiss B, Thornton C. Lipopolysaccharide-induced alteration of mitochondrial morphology induces a metabolic shift in microglia modulating the inflammatory response in vitro and in vivo. Glia. 2019;67(6):1047-61. PMID: 30637805. Available from: 10 1002/glia.23587.

18. Liu Z, Xie L, Bian T, Qi G, Wang Z. (3R)-5,6,7-trihydroxy3-isopropyl-3-methylisochroman-1-one reduces lipoteichoic acid-induced damage in rat cardiomyoblast cells. The Anatolian Journal of Cardiology. 2018;19(3):198-204. PMID: 29521314. Available from: 10.14744/AnatolJCardiol.2018. 71542.

19. Schilling JD, Machkovech HM, He L, Diwan A, Schaffer JE. TLR4 activation under lipotoxic conditions leads to synergistic macrophage cell death through a TRIF-dependent pathway. Journal of Immunology (Baltimore, Md: 1950). 2013;190(3):1285-96. PMID: 23275600. Available from: 10. 4049/jimmunol.1202208.

20. Aits S, Jäättelä M. Lysosomal cell death at a glance. Journal of Cell Science. 2013;126(Pt 9):1905-12. PMID: 23720375. Avail- able from: 10.1242/jcs.091181.

21. Klein JB, Buridi A, Coxon PY, Rane MJ, Manning T, Kettritz R. Role of extracellular signal-regulated kinase and phosphatidylinositol-3 kinase in chemoattractant and LPS delay of constitutive neutrophil apoptosis. Cellular Signalling. 2001;13(5):335-43. PMID: 11369515. Available from: 10.1016/ S0898-6568(01)00151-6.

22. Wu HH, Hsieh WS, Yang YY, Tsai MC. Lipoteichoic acid induces prostaglandin $\mathrm{E}(2)$ release and cyclooxygenase-2 synthesis in rat cortical neuronal cells: involvement of PKCepsilon and ERK activation. Life Sciences. 2006;79(3):272-80. PMID: 16464474. Available from: 10.1016/j.lfs.2006.01.004.

23. Bagaev AV, Garaeva AY, Lebedeva ES, Pichugin AV, Ataullakhanov RI, Ataullakhanov FI. Elevated pre-activation basal level of nuclear NF- $\kappa$ B in native macrophages accelerates LPS-induced translocation of cytosolic NF- $\kappa$ B into the cell nucleus. Scientific Reports. 2019;9(1):4563. PMID: 30872589. Available from: 10.1038/s41598-018-36052-5.

24. Zhang FX, Kirschning CJ, Mancinelli $R$, Xu XP, Jin Y, Faure E. Bacterial lipopolysaccharide activates nuclear factor-kappaB through interleukin-1 signaling mediators in cultured human dermal endothelial cells and mononuclear phagocytes. The Journal of Biological Chemistry. 1999;274(12):7611-4. PMID: 10075645. Available from: 10.1074/jbc.274.12.7611.

25. Kuo CT, Chiang LL, Lee CN, Yu MC, Bai KJ, Lee HM. Induction of nitric oxide synthase in RAW 264.7 macrophages by lipoteichoic acid from Staphylococcus aureus: involvement of protein kinase $\mathrm{C}$ - and nuclear factor-kB-dependent mechanisms. Journal of Biomedical Science. 2003;10(1):136-45. PMID: 12607534. Available from: 10.1159/000068076.

26. Dessing MC, Schouten M, Draing C, Levi M, von Aulock S, van der Poll T. Role played by Toll-like receptors 2 and 4 in lipoteichoic acid-induced lung inflammation and coagulation. The Journal of Infectious Diseases. 2008;197(2):245-52. PMID: 18179383. Available from: 10.1086/524873.

27. Kao SJ, Lei HC, Kuo CT, Chang MS, Chen BC, Chang YC. Lipoteichoic acid induces nuclear factor-kappaB activation and nitric oxide synthase expression via phosphatidylinositol 3-kinase, Akt, and p38 MAPK in RAW 264.7 macrophages. Immunology. 2005;115(3):366-74. PMID: 15946254. Available from: 10.1111/j.1365-2567.2005.02160.x.

28. Britt RD, Locy ML, Tipple TE, Nelin LD, Rogers LK. Lipopolysaccharide-induced cyclooxygenase-2 expression in mouse transformed Clara cells. Cellular Physiology and Biochemistry. 2012;29(1-2):213-22. PMID: 22415090. Available from: 10.1159/000337602.

29. Eliopoulos AG, Dumitru CD, Wang CC, Cho J, Tsichlis PN. Induction of COX-2 by LPS in macrophages is regulated by Tpl2-dependent CREB activation signals. The EMBO Journal. 2002;21(18):4831-40. PMID: 12234923. Available from: 10.1093/emboj/cdf478.

30. McElroy SJ, Hobbs S, Kallen M, Tejera N, Rosen MJ, Grishin A. Transactivation of EGFR by LPS induces COX-2 expression in enterocytes. PLoS One. 2012;7(5):e38373. PMID: 22675459. Available from: 10.1371/journal.pone.0038373.

31. Nagano S, Otsuka T, Niiro H, Yamaoka K, Arinobu Y, Ogami E. Molecular mechanisms of lipopolysaccharide-induced cyclooxygenase-2 expression in human neutrophils: involvement of the mitogen-activated protein kinase pathway and regulation by anti-inflammatory cytokines. International Immunology. 2002;14(7):733-40. PMID: 12096032. Available from: 10.1093/intimm/dxf038.

32. Wu HH, Hsieh WS, Yang YY, Tsai MC. Lipoteichoic acid induces prostaglandin $\mathrm{E}(2)$ release and cyclooxygenase-2 synthesis in rat cortical neuronal cells: involvement of PKCepsilon and ERK activation. Life Sciences. 2006;79(3):272-80. PMID: 16464474. Available from: 10.1016/j.lfs.2006.01.004.

33. Lee IT, Lee CW, Tung WH, Wang SW, Lin CC, Shu JC. Cooperation of TLR2 with MyD88, PI3K, and Rac1 in lipoteichoic acid-induced CPLA2/COX-2-dependent airway inflammatory responses. American Journal of Pathology. 2010;176(4):167184. PMID: 20167866. Available from: 10.2353/ajpath.2010. 090714. 
Ready to submit your manuscript? Choose Biomedpress and benefit from:

- Fast, convenient online submission

- Through peer-review by experienced researchers

- Rapid publication on acceptance

- Free of charge (without publication fees)

Learn more http://www.biomedpress.org/journals/

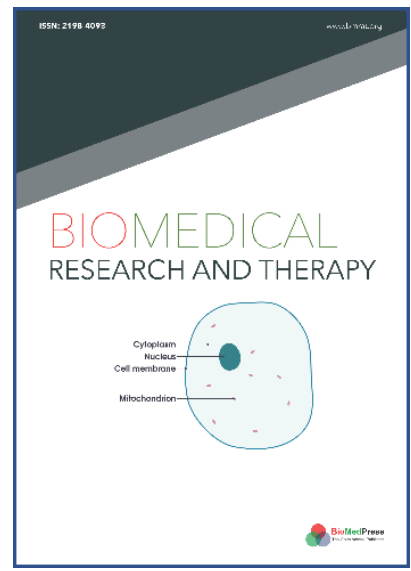

\title{
Biomedical Research and Therapy
}

Indexed: Web of Science (ESCl), Embase, Google Scholar

Journal Citation Indicator (2020): 0.16

Acceptance Rate (2020): 54.32\%

Article Publishing Charge: Free

Submission to first editorial decision: 27 days

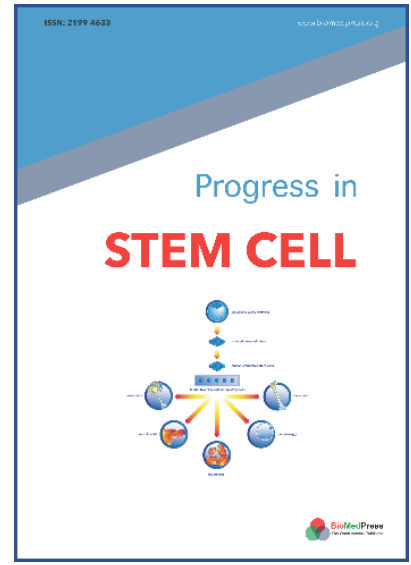

\section{Progress in Stem Cell}

Indexed: Embase, Google Scholar

Acceptance Rate (2020): 78.19\%

Article Publishing Charge: Free

Submission to first editorial decision: 19 days

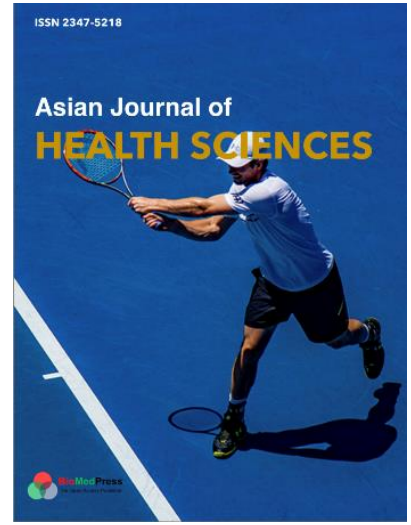

\author{
Asian Journal of Health Sciences \\ Indexed: Google Scholar \\ Acceptance Rate (2020): 72.89\% \\ Article Publishing Charge: Free \\ Submission to first editorial decision: 16.5 days
}

